PRESENT STATUS OF THE

POLYMERIC-MATERIALS SCREENING

PROGRAM FOR THE LLL GEOTHERMAL PROJECT

Lyman E. Lorensen

C. M. Walkup

E. T. Mones

July 9, 1975

Prepared for U.S. Energy Research \& Development

Administration under contract No. W-7405-Eng-48

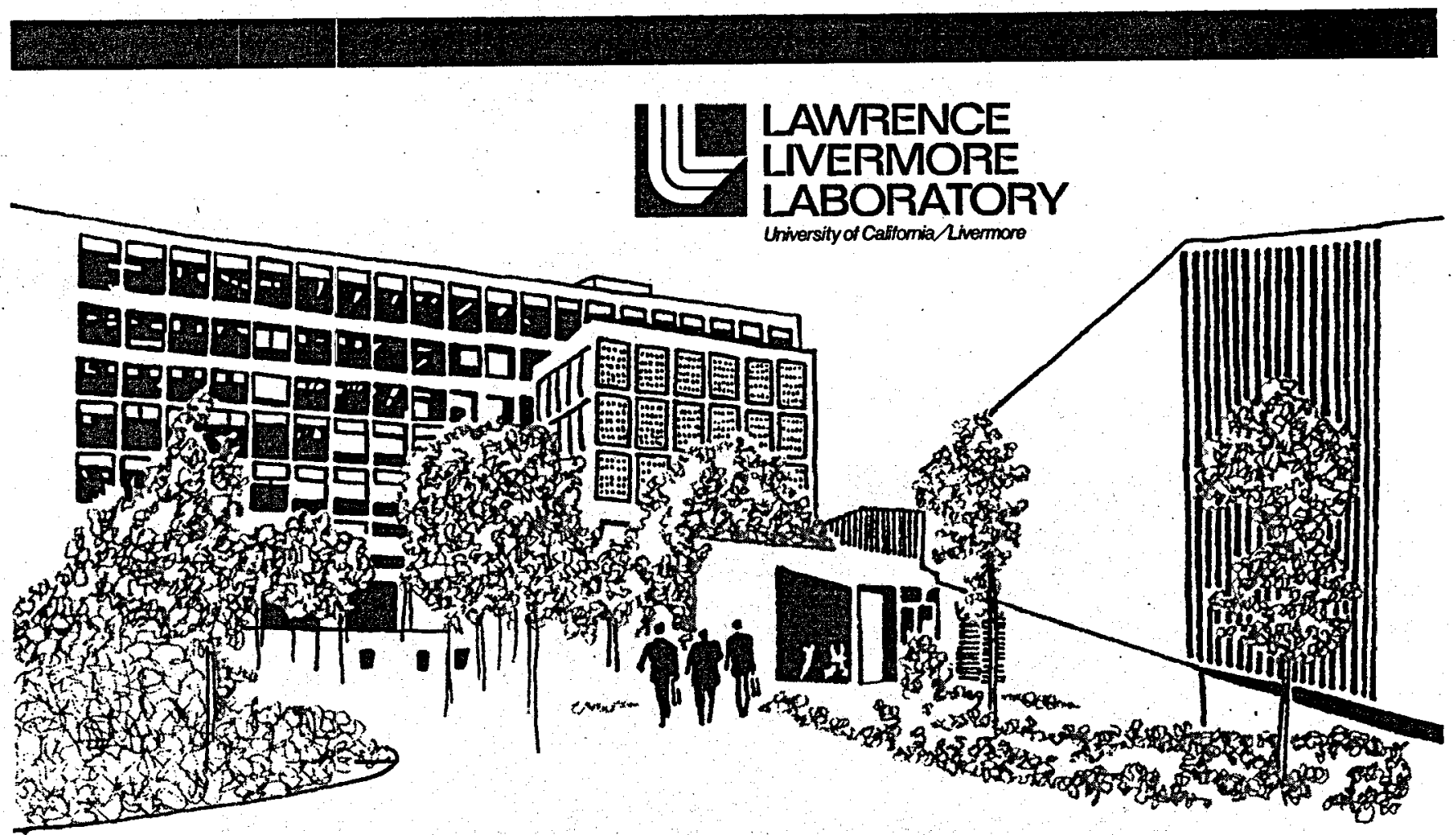

Dissuartew ar MASTER 


\section{DISCLAIMER}

This report was prepared as an account of work sponsored by an agency of the United States Government. Neither the United States Government nor any agency Thereof, nor any of their employees, makes any warranty, express or implied, or assumes any legal liability or responsibility for the accuracy, completeness, or usefulness of any information, apparatus, product, or process disclosed, or represents that its use would not infringe privately owned rights. Reference herein to any specific commercial product, process, or service by trade name, trademark, manufacturer, or otherwise does not necessarily constitute or imply its endorsement, recommendation, or favoring by the United States Government or any agency thereof. The views and opinions of authors expressed herein do not necessarily state or reflect those of the United States Government or any agency thereof. 


\section{DISCLAIMER}

Portions of this document may be illegible in electronic image products. Images are produced from the best available original document. 


\section{NOTICE}

"This report was prepared as an account of work sponsored by the United States Government. Neither the United States nor the United States Energy Research \& Development Administration, nor any of their employees, nor any of their contractors, subcontractors, or their employees, makes any warranty, express or implied, or assumes any legal liability or responsibility for the accuracy, completeness or usefulness of any information, apparatus, product or process disclosed or apparatus, product or process disclo infringe privately-owned sights."

Printed in the United States of America Available from

National Technical Information Service U. S. Department of Commerce 5285 Port Royal Road

Springfield, Virginia 22151

Price: Printed Copy \$ * Microfiche \$2.25

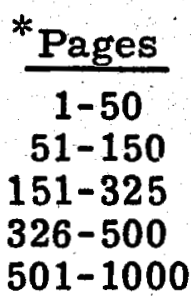

NTIS

Selling Price

$\$ 4.00$

$\$ 5.45$

$\$ 7.60$

$\$ 10.60$

$\$ 13.60$ 


\section{UCRL-51843 \\ PRESENT STATUS OF THE \\ POLYMERIC-MATERIALS SCREENING \\ PROGRAM FOR THE LLL GEOTHERMAL PROJECT \\ Lyman E. Lorensen \\ C. M. Walkup \\ E. T. Mones}

MS. date: June 12, 1975

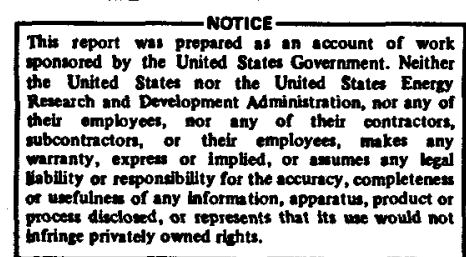




\section{Contents}

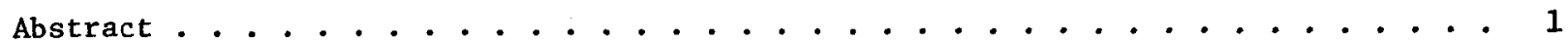

Introduction ........................... 1

Interim Results ....................... 2

Hot-Brine Tests in Stainless Steel Pressure Vessels . . . . . . . . . . 6

Tests at $300^{\circ} \mathrm{C} \ldots \ldots \ldots \ldots$

Tests at $250^{\circ} \mathrm{C} \ldots \ldots \ldots \ldots$

Materials Tests at Geothermal Wells . . . . . . . . . . . . . . . 11

Test Results on Nozzles ........................ 12

Test Results on Wear Plates . . . . . . . . . . . . . . 15

Equipment ........................ 15

Part Fabrication . . . . . . . . . . . . . . . . 16

Future Work . . . . . . . . . . . . . . . . . . . 16

Acknowledgments . . . . . . . . . . . . . . . 16

References . . . . . . . . . . . . . . . . . . . 18

Appendix ........................... . . . 19

Detailed Test Results on Nozzles.................... 19

Detailed Test Results on Wear Plates . . . . . . . . . . . . . 26

References ......................... 26 


\title{
PRESENT STATUS OF THE POLYMERIC-MATERIALS SCREENING PROGRAM FOR THE LLL GEOTHERMAL PROJECT
}

\begin{abstract}
Progress is reported on the continuing experimental program aimed at finding highperformance polymeric materials for use in the Lawrence Livermore Laboratory "Total Flow" process for producing electricity by the use of geothermal brines. Out of a total of 29 polymeric materials which have been screened in a $300^{\circ} \mathrm{C}$ static brine-test, 7 types of polymers have withstood tests up to $555 \mathrm{hr}$ with less than $10 \%$ weight loss. Also, 5 polymeric materials were tested at $250^{\circ} \mathrm{C}$ for possible service in the less demanding plant components. Polymer structures containing either substantial aromaticity, fluorine, carbonized structure, or aliphatic unsaturation which as been crosslinked,

show considerable stability. The presence of water-sensitive groups such as imide, amide, or ester is detrimental even in very therma11y stable polymers. Eight nozzles and two wear plates were tested in the field. While plugging of nozzle throats by well debris made interpretation of results difficult, both the nozzles and a wear plate of Tefion PFA showed minimal scale deposttion and erosion after more than 100 hours of operation. Teflon TFE, and to a much lesser extent Teflon PFA, developed surface fibrils while subjected to well flow. Equipment corrosion problems, acquisitions, part fabrication, critical-path planning and future-work plans are discussed.
\end{abstract}

\section{Introduction}

Lawrence Livermore Laboratory (LLL) has initiated a program aimed at economic generation of electrical energy from hot geothermal brine. In this scheme (called the "Total Flow" process"), hot, pressurized geothermal brine is piped to the surface of the ground, directed through special nozzles against turbine blades, and then condensed for reinjection via deep wells. Because of the difficult environmental problems associated with handling hot, high-pressure brine, LLL has been conducting a special program aimed at selecting and screening materials for the down-hole brine delivery pipe, nozzles, turbines, condenser parts and brine reinjection plpes. In addition to mechanical strength, desirable properties of these materials include thermal stability, resistance to corrosion and chemical attack, erosion resistance, and antiscaling characteristics. This program, as described in Ref. 2, has been under way for some time and has been supplemented 
in a number of specific respects. Among these are:

1. Information available in the literature and from vendors has made it unnecessary to conduct oven and thermogravimetric analysis (TGA) thermal stability tests for characterizing materials.

2. Hot-brine-flow-erosion tests are being conducted at wells rather than in the laboratory.

3. Our tests now include polymerlined metal pipe as well as filamentwound pipe.

4. The LLL Geothermal Test Facility will include salt-free two-phase "clean steam" tests of nozzles and wear plates. A flowchart of events in the complete testing and evaluation program is shown in Fig. 1. The steps in this sequence are shown in a format corresponding to the Critical Path method as prepared by an LLL computer code.

5. Present turbine designs require use of specialized protective coatings. Plans for selecting and evaluating such coatings are now under way.

6. Nozzle designs have been enlarged to minimize debris entrapment.

7. In order to better simulate turbine geometry, a black-type wear plate is being exposed to edge-on flow testing.

\section{INTERIM RESULTS}

Out of a total of 29 materials which have been screened in the $300^{\circ} \mathrm{C}$ static brine test, 7 types or families of polymers have withstood longer term tests (up to $555 \mathrm{hr}$ ) with less than $10 \%$ weight loss. Five materials tested at $250^{\circ} \mathrm{C}$ for possible service in less demanding components show reduced but unpredictable weight losses. Polymer structures containing, either substantial aromaticity, fluorine, carbonized structures, or aliphatic unsaturation which has been crosslinked show considerable stability. The presence of water-sensitive groups such as imide, amide, or ester is detrimental even in very thermally stable polymers. Eight nozzles and two wear plates have been exposed to flow from a geothermal well. While plugging by well debris made interpretation of nozzle results difficult, both nozzles and a wear plate of Teflon PFA* showed minimal scale deposition and erosion after more than 100 hours of operation. Nozzle designs have been enlarged to minimize debris entrapment. Also, a blade-type wear plate is being exposed to edge-on-flow testing in order to better simulate turbine geometry. Present turbine designs will require some protective coatings and plans for selecting and evaluating such coatings are now under way. 


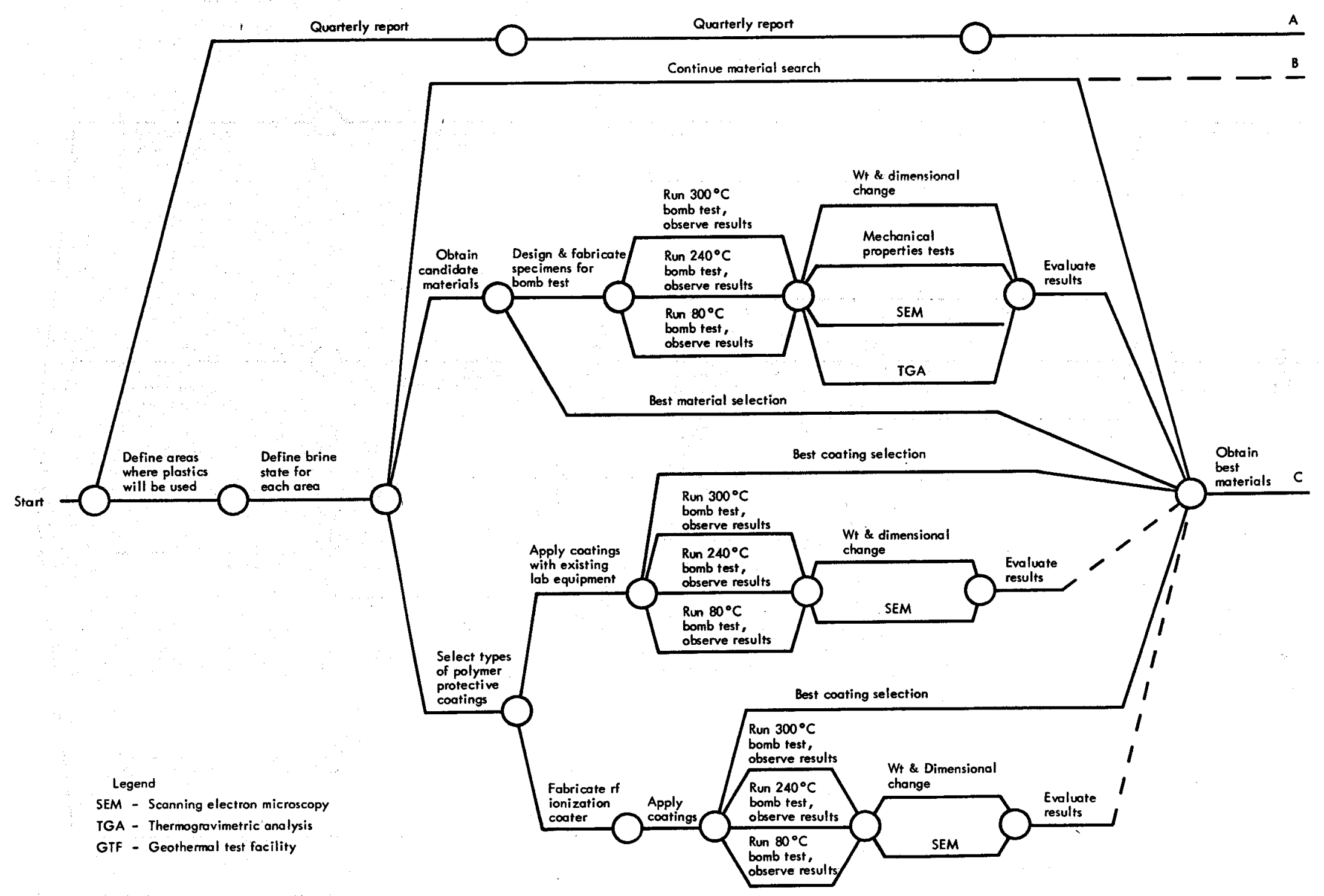

Fig. 1A. Critical-path chart for the materials-screening program (part 1) 


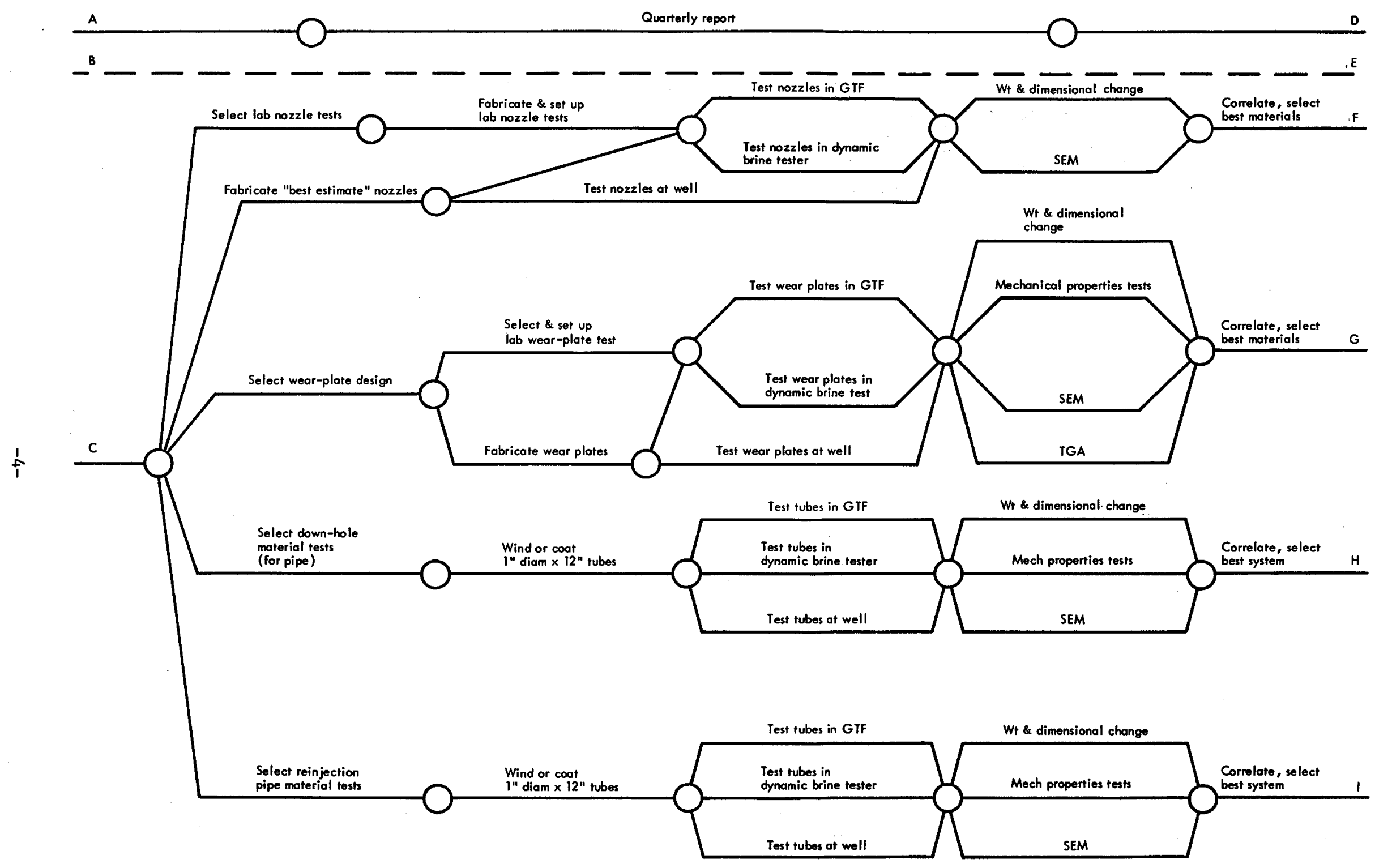

Fig. 1B. Critical-path chart for the materials-screening program (part 2) 


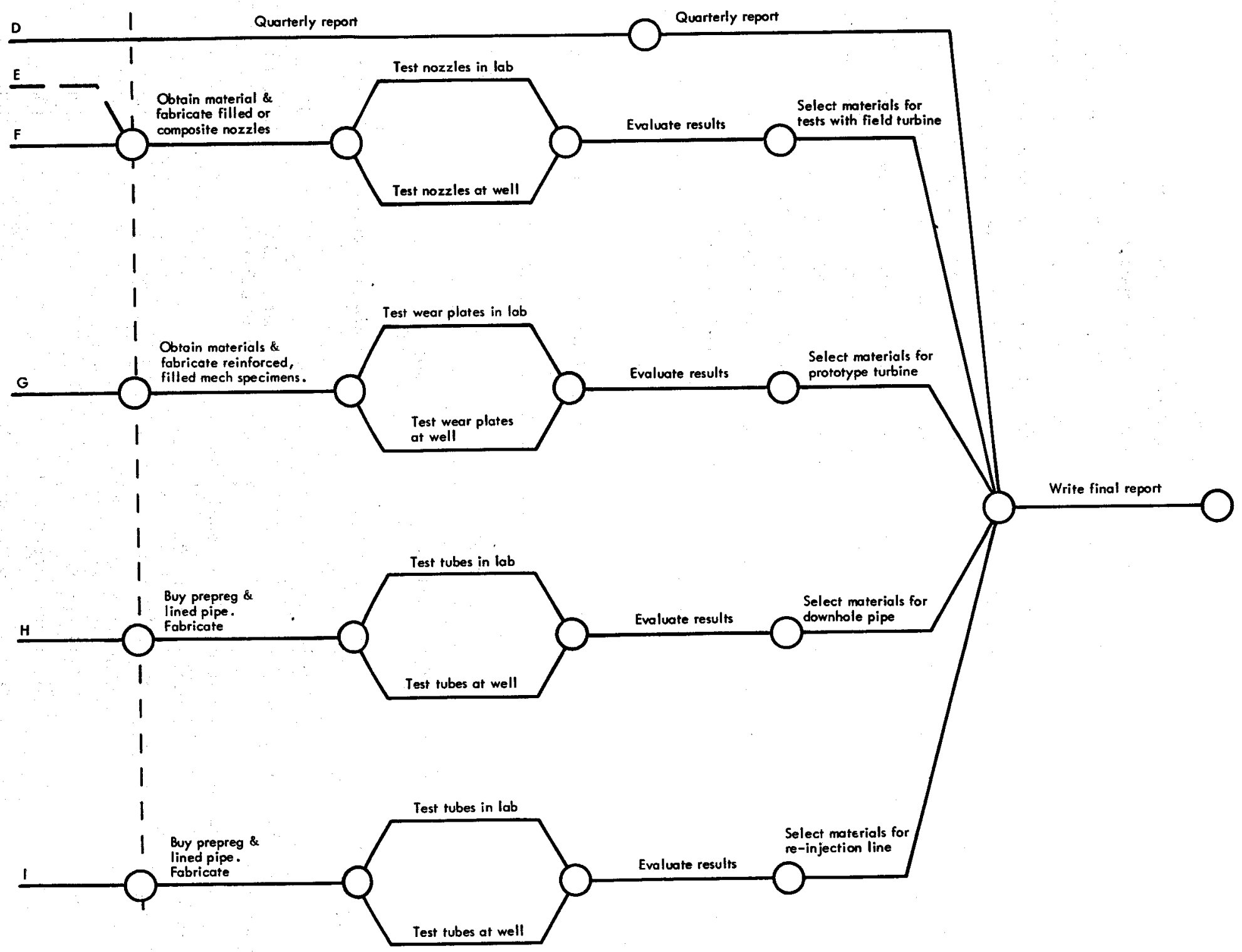

Fig. 1C. Critical-path chart for the materials-screening program (part 3) 


\section{Hot-Brine Tests in Stainless Steel Pressure Vessels}

TESTS AT $300^{\circ} \mathrm{C}$

Since the start of the testing and evaluation program a total of 29 materials has been examined. The results of those tests are listed in Table 1, for materials which lost more than $10 \%$ weight after 72 hours at $300^{\circ} \mathrm{C}$, and Table 2 for those which lost less than $10 \%$ weight after 72 hours at $300^{\circ} \mathrm{C}$. The percent weight changes with heating time for the better materials are plotted in Figs. $2 \mathrm{~A}$ and $2 \mathrm{~B}$. As indicated in these figures, several samples showed a rather rapid initial weight loss, probably from loss of monomer, other low molecular weight fragments, or water.
Stabilization then followed. Six materials, a carbon/graphite cloth heatshield-type composite, two DuPont Teflons, Hercules H-resins, Whittaker Imidite polybenzimidazole, polyphenylquinoxaline/ Modmor II carbon fiber and a Ferro phenolic, all show very good stability far beyond 72 hours. A seventh material type, Firestone Dienite, shows some promise in certain versions. This is especially encouraging in view of the low cost of 1,2-polybutadiene.

It should be noted that some of the materials 1isted in Tables 2 and 3 contained nonpolymeric additives such as fillers which function to improve

Table 1.

Materials showing more than 10 wt\% loss after $72 \mathrm{hr}$ in $300^{\circ} \mathrm{C}$ synthetic brine

\begin{tabular}{lllc}
\hline \multicolumn{1}{c}{$\begin{array}{c}\text { Material class } \\
\text { or type }\end{array}$} & \multicolumn{1}{c}{$\begin{array}{c}\text { Supplier and/or } \\
\text { trade name }\end{array}$} & Filler & $\begin{array}{c}\text { Weight loss } \\
(\%)\end{array}$ \\
\hline $\begin{array}{l}\text { Polyphenylene } \\
\text { Sulfide (PPS) }\end{array}$ & Phillips-Ryton & $40 \%$ glass fiber & Flowed $^{\mathrm{a}}$ \\
$\begin{array}{l}\text { Polyphenylene } \\
\text { Sulfide (PPS) }\end{array}$ & Phillips-Ryton & $40 \%$ glass fiber & Flowed $^{\mathrm{a}}$ \\
Polyimide & Meldin & & 31 \\
$\begin{array}{l}\text { Epoxy/Thornel } 50 \mathrm{~S} \\
\text { Carbon fiber }\end{array}$ & & Estimated $60 \%$ & $43(100)^{\mathrm{b}}$ \\
Aromatic Polyester & Carborundum-Ekono1 900 & & 69 \\
Carborane & 01in-Dexsil-201 & & 82 \\
Polyimide & DuPont-NR150B & & 100 \\
Polyimide & DuPont-NR150B & & 100 \\
Polyimide & DuPont Vespel & & 100 \\
Polyimide & Monsanto-Skybond 700 & & 100 \\
Polyamide & DuPont-KS Polyamide & & 100 \\
\hline
\end{tabular}

aPS flowed during the test, breaking into smaller pleces some of which could not be recovered. It was not felt that the polymer was necessarily degraded, however.

${ }^{b}$ Predicted loss if the sample had been $100 \%$ polymer. 
Table 2.

Materials showing less than $10 \mathrm{wt} \%$ loss after $72 \mathrm{hr}$ in $300^{\circ} \mathrm{C}$ synthetic brine

\begin{tabular}{|c|c|c|c|}
\hline $\begin{array}{l}\text { Material class } \\
\text { or type }\end{array}$ & $\begin{array}{l}\text { Supplier and/or } \\
\text { trade name }\end{array}$ & Filler & $\begin{array}{l}\text { Weight change } \\
(\%)\end{array}$ \\
\hline $\begin{array}{l}\text { Polybenzimidazole } \\
\text { (PBI) foam }\end{array}$ & & & $+79^{a}$ \\
\hline $\begin{array}{l}\text { Polyimide/carbon fiber } \\
\text { Kermid } 601 / \text { Thorne1 } 400\end{array}$ & & $\begin{array}{l}\text { Estimated } 60 \% \\
\text { carbon fiber }\end{array}$ & $+35^{b}$ \\
\hline Polyaromatic & Hercules H-Resin-HA-54 & $40 \mathrm{wt} \% \mathrm{Al}_{2} \mathrm{O}_{3}$ & +6 \\
\hline $\begin{array}{l}\text { Carbon/carbon fiber } \\
\text { composite }\end{array}$ & & & +4 \\
\hline $\begin{array}{l}\text { Polytetrafluoro- } \\
\text { ethylene }\end{array}$ & DuPont Teflon TFE & & +1 \\
\hline $\begin{array}{l}\text { Fluorinated } \\
\text { (perfluoroalkoxy) } \\
\text { copolymer }\end{array}$ & DuPont Teflon PFA & & 0 \\
\hline Polyaromatic & Hercules H-104 Resin & & 0 \\
\hline Polyaromatic & Hercules H-124, & 50 wt\% graphite & 0 \\
\hline $\begin{array}{l}\text { Polyphenylquinoxaline/ } \\
\text { carbon fiber }\end{array}$ & & $\begin{array}{l}\text { Estimated } 60 \% \\
\text { carbon fiber }\end{array}$ & 0 \\
\hline Polyaromatic & $\begin{array}{l}\text { Hercules HA-54'Resin } \\
\text { Stabilized }\end{array}$ & $40 \mathrm{wt} \% \mathrm{Al}_{2} \mathrm{O}_{3}$ & $-1(1.7)^{c}$ \\
\hline Poly-1,2-butadiene & Firestone Dienite X -644 & $10 \%$ chopped glass & $-2(2.2)^{c}$ \\
\hline Phenolic/fiberglass & Ferro Corp. & $\begin{array}{l}\text { Estimated } 70 \% \\
\text { fiberglass }\end{array}$ & $-3(10)^{c}$ \\
\hline Poly-1,2-butadiene & Firestone Dienite X -644 & $10 \%$ chopped glass & $-5(5.6)^{c}$ \\
\hline Poly-1,2-butadiene & Firestone Dientte X-556 & & -5 \\
\hline Polybenzimidazole & Whittaker Imidite 2803 & . & -5 \\
\hline Polybenzimidazole & Whittaker Imidite 2803 & & -5 \\
\hline Poly-1,2-butadiene & Firestone Dienite X-643 & $20 \%$ chopped glass & $-8(10)^{c}$ \\
\hline Poly-1,2-butadiene & Firestone Dientte X-555 & $\vdots$ & -9 \\
\hline Poly-1,2-butadiene & Firestone Dienite X-555 & & -9 \\
\hline
\end{tabular}

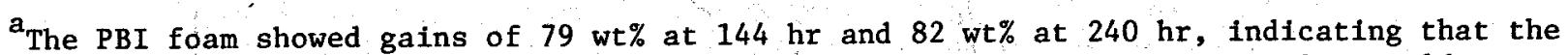
foam had filled with salts from the $25 \mathrm{wt} \%$ salt-content brine. These salts could not be washed out read $11 y$ and remained after drying the sample to constant weight.

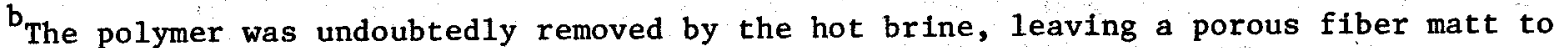
collect salts.

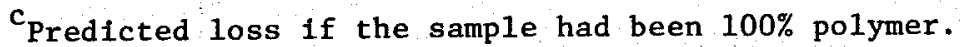




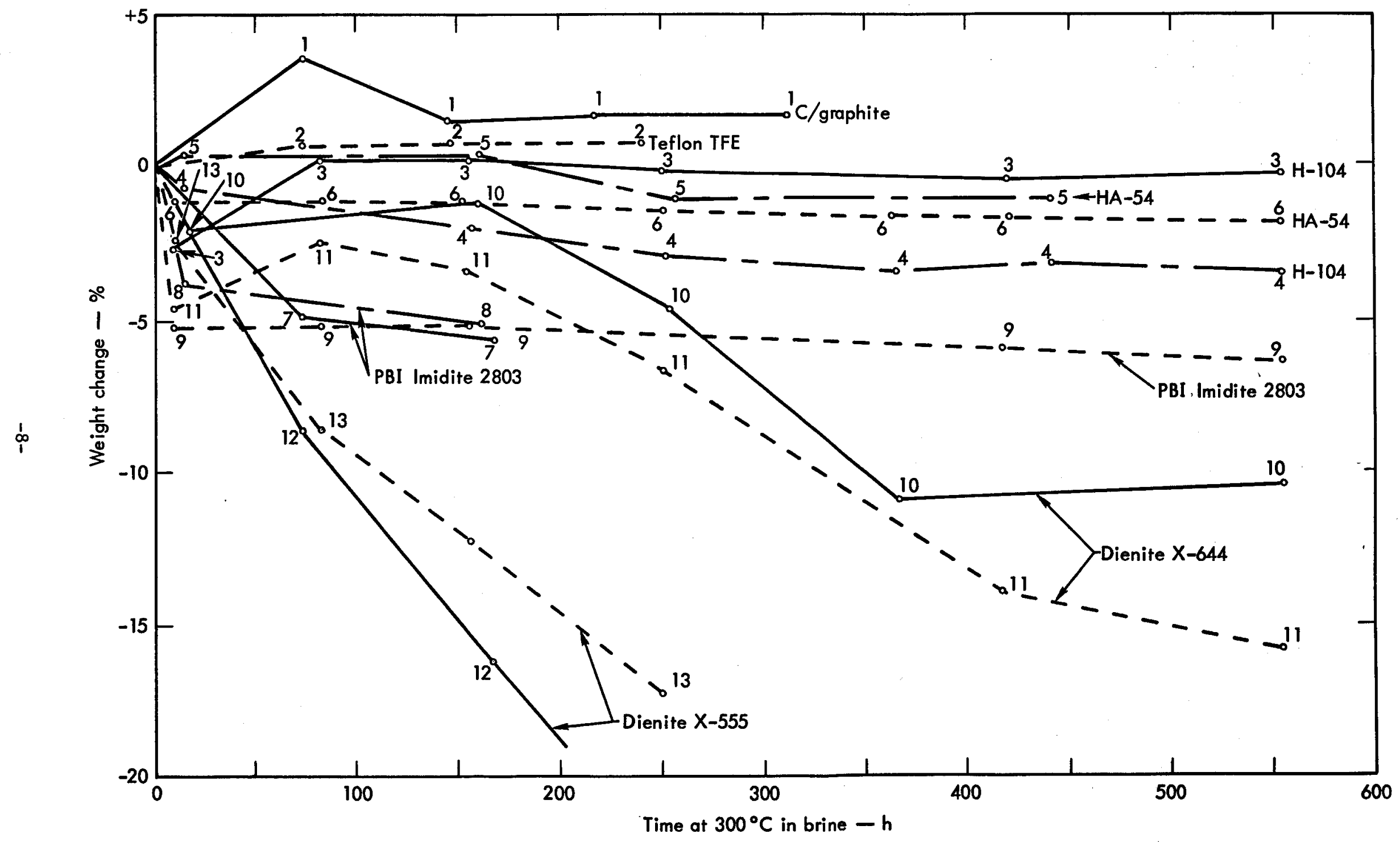

Fig. 2A. Weight loss vs time in $300^{\circ} \mathrm{C}$ brine (part 1)

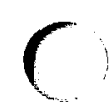




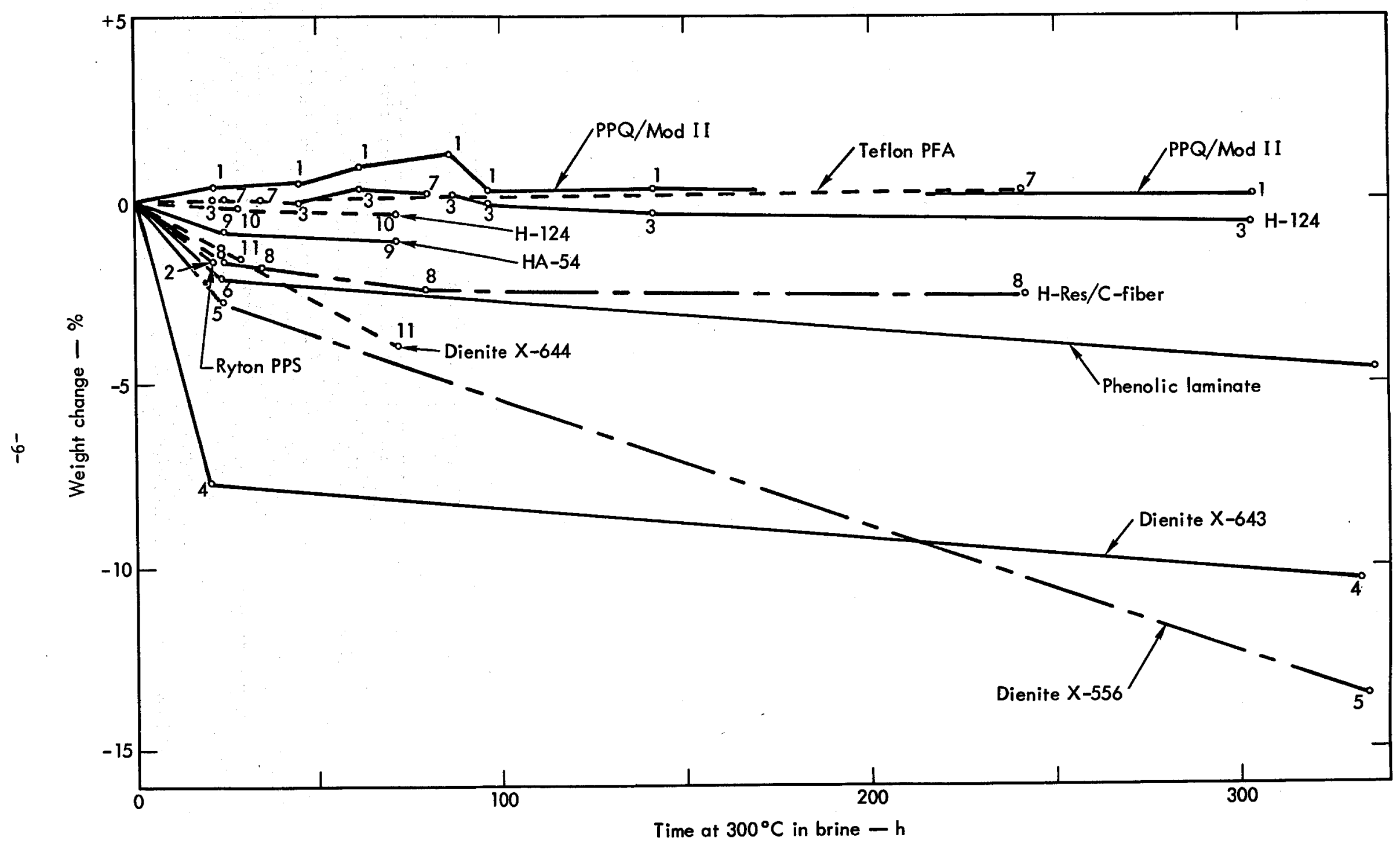

Fig. 2B. Weight 10 ss vs time in $300^{\circ} \mathrm{C}$ brine (part 2) 
certain performance factors. In Tables 1 and 2, both observed losses and losses normalized to $100 \%$ polymer are given since we do not always know filler contents exactly nor whether the filler remains unattacked in hot brine. Because further study needs to be done to determine the mechanism of weight loss, the most reliable comparisons are anong materials which are $100 \%$ polymer.

It was hoped that polyimides would perform better than was actually observed. Reference 3 notes that the polyimide film, Kapton, remains flexible after 1 year in boiling water. Other references are not so optimistic, stating that resistance to superheated steam is low, etc. ${ }^{4}$ Thermal stability of the polyimides in at least some samples should be quite adequate, particularly for those formed by the condensation process. Other desirable properties of the polyimides include strength, oxidative stability, ease of fabrication (including filament winding), and availability at a reasonable cost.
However representative materials failed (by foaming or dissolving) in as short a time as 21 hours. See Table 3. Seven addition types of polyimides are currently available as well as at least two condensation types (Vespel or Kapton, and Skygard). See Ref. 5 .

TESTS AT $250^{\circ} \mathrm{C}$

Materials which fail the $300^{\circ} \mathrm{C}$ brine test may still be useful for the lower temperature application in nozzles $\left(240^{\circ} \mathrm{C}\right)$, turbine parts $\left(60^{\circ} \mathrm{C}\right)$ and condenser parts $\left(50^{\circ} \mathrm{C}\right)$. A further incentive for conducting tests at lower temperatures is that the less therma11y stable candidates are often economically very attractive. Results of initial tests of such materials are given in Table 4. As expected, the observed weight losses are higher at $300^{\circ} \mathrm{C}$ than at $250^{\circ} \mathrm{C}$. Differences between the observed and calculated $300^{\circ} \mathrm{C}$ values result from the fact that the calculated values were extrapolated from the observed

Table 3.

Effect of $300^{\circ} \mathrm{C}$ brine on polyimides

\begin{tabular}{|c|c|c|}
\hline Material & 21 hours & $\begin{array}{l}\text { ter indicated heating time } \\
72 \text { hours }\end{array}$ \\
\hline Meldin & & $-31 \%$ (brittle, porous residue) $^{a}$ \\
\hline DuPont NR150B & & $-100 \%$ \\
\hline Kerimid $601 /$ Thornel 400 & & $+35 \%\left(\right.$ carbon fibers trapped salts) ${ }^{a}$ \\
\hline Skybond 700 & $\begin{array}{l}\text { Foamed } \\
\text { residue }\end{array}$ & . \\
\hline DuPont NR150B & $-100 \%^{a}$ & \\
\hline Vespel & $\begin{array}{l}\text { Charred } \\
\text { residue }\end{array}$ & . \\
\hline
\end{tabular}

\footnotetext{
a Percent weight change
} 
Table 4.

Weight loss vs time in $250^{\circ} \mathrm{C}$ artificial brine

\begin{tabular}{|c|c|c|c|c|c|c|}
\hline Material & $\begin{array}{l}\text { Wei. } \\
250^{\circ} \mathrm{C} \\
(\%)\end{array}$ & 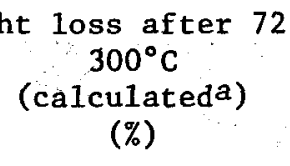 & $\begin{array}{l}\text { hours } \\
300^{\circ} \mathrm{C} \\
\text { (observed) } \\
(\%)\end{array}$ & $\begin{array}{l}\text { Weight } \\
250^{\circ} \mathrm{C} \\
(\%)\end{array}$ & $\begin{array}{c}\text { 1oss after } 202 \\
300^{\circ} \mathrm{C} \\
\text { (calculated) } \\
(\%)\end{array}$ & $\begin{array}{l}\text { hours } \\
300^{\circ} \mathrm{C} \\
\text { (observed) } \\
\text { (\%) }\end{array}$ \\
\hline Dienite X-555 & $-0.11 \%$ & -3.5 & -8.9 & -1.7 & -54 & -15 \\
\hline Dienite X-644 & -1.9 & -61 & -3.6 & -2.3 & -74 & -7 \\
\hline Hercules H-104 & -0.4 & -12.8 & -0.6 & -.9 & -29 & -0.2 \\
\hline Hercules HA-54 & -0.2 & -6.4 & -1 & 0 & - & - \\
\hline Imidite 2803 & -3.9 & -100 & -5 & -4.9 & -100 & -6 \\
\hline
\end{tabular}

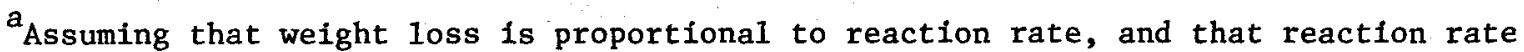
follows the Arrhenius approximation of doubling with each $10^{\circ} \mathrm{C}$ rise in temperature.

$250^{\circ} \mathrm{C}$ values. The latter, however, are an uncertain basis for such calculations due to the 1ikely contribution of non-degradative processes (monomer or water loss) to the relatively small total losses involved at $250^{\circ} \mathrm{C}$. Particularly encouraging is the improved performance of the inexpensive 1,2-polybutadiene "Dienites" at $250^{\circ} \mathrm{C}$.

Some generalizations regarding the ability of various materials to survive hot brine can now be made. Hydrolyzable linkages within molecules are undesirable, as evidenced by the poor performance of polyimide, the aromatic polyester, the carborane and the polyamide. Some of the crosslinking phenomena involved in the cure of epoxy resin are also reversible at high temperatures in the presence of water. In contrast to these sources of instabi1ity, a high degree of aromaticity combined with water-insensitive linkages (such as are found in $\mathrm{PBI}, \mathrm{H}$-resins, $\mathrm{PPQ}$ and phenolic) confers stability. The highmelting fluorocarbons, Teflon TFE and PFA, as well as the highly crosslinked 1,2polybutadienes also successfully withstand the $300^{\circ} \mathrm{C}$ brine. There is some evidence that the presence of stabilizers (termed "Antioxidants/Antidegradants" by Firestone) is helpful in the case of the butadiene polymers.

\section{Materials Tests at Geothermal Wells}

Following limited initial static tests in a deep we $11^{2}$, nozzles and wear plates were prepared for dynamic tests on the stream from a flowing well. These tests were designed to show differences in erosion resistance of materials under the hot corrosive well conditions. Results with wear plates would offer guidance for selecting materials for turbine blades. The nozzle design is shown in Fig. 3. 


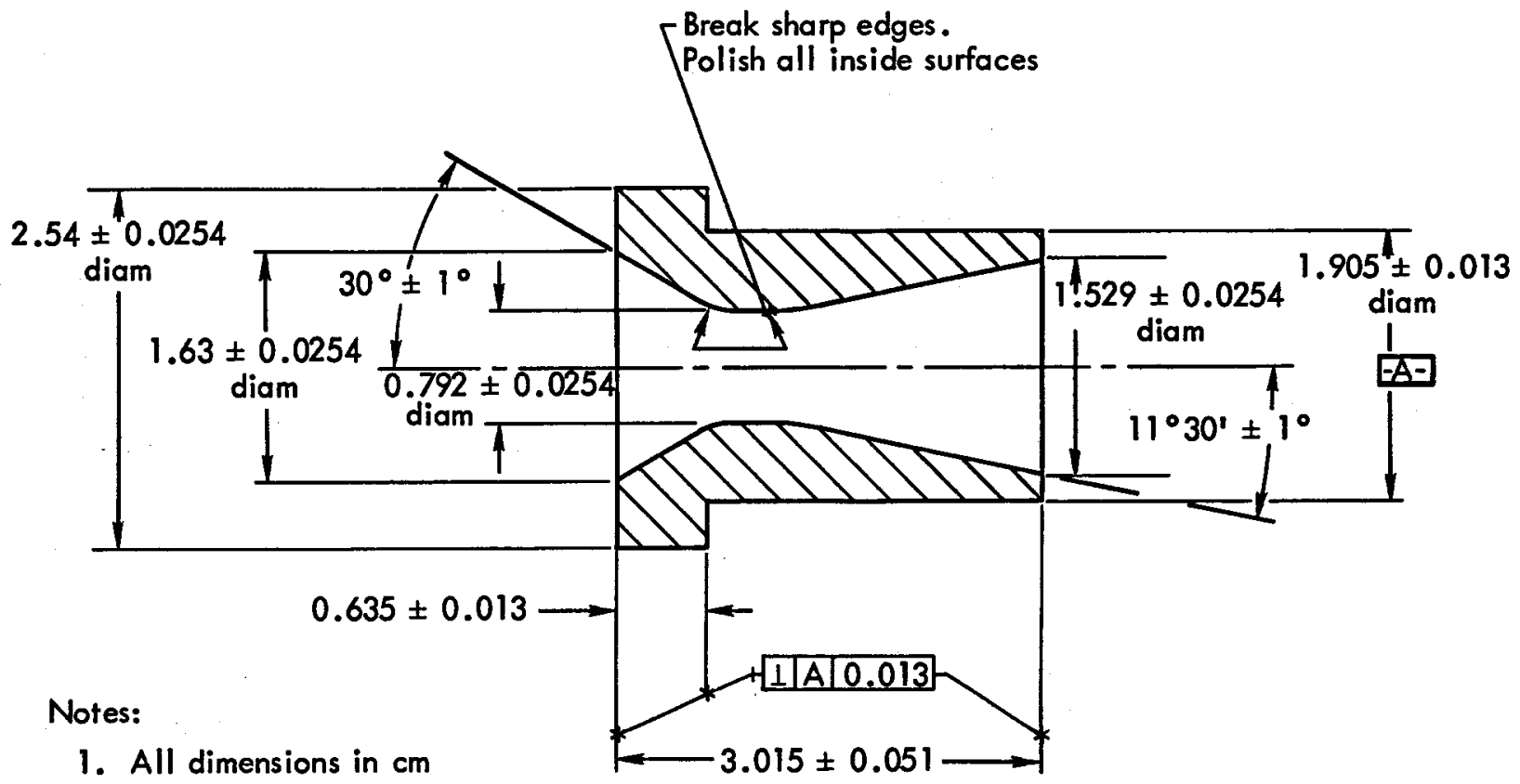

2. All diam $1 \mathrm{~A} \mid 0.051$

\section{Direction of flow}

Fig. 3. Nozzle design for materials tests

The wear plates were flat specimens approximately $7.6 \times 10.2 \times 0.64 \mathrm{~cm}$ which were clamped on the exit side of the nozzle at such an angle that the expanded stream impinged on the central area.

Four nozzles and their wear plates were mounted on a manifold inside a large chamber. Brine from the well entered on one side, passed through the manifold and four test nozzles, struck the wear plates, then exited at the opposite end (Figs. 4 and 5).

TEST RESULTS ON NOZZLES

Seven nozzles made from five different materials were tested, each for from 110 to 130 hours. Brief comments on each follow. Detailed comments and photographs of these nozzles are found in the Appendix, Figures A1 through A15.
Nozzle N-1. Carbon Fiber or Felt Impregnated With Carbon Via the Carbon Vapor Deposition (CVD) Process.

After testing, this nozzle (Fig. A-1) and several others were partially blocked with pieces of scale debris, probably from upstream valves or pipe. These pieces were simply too large to pass the small throats of the nozzles. The resulting choking off of flow allowed evaporation to deposit scale. The scaling pattern with $\mathrm{N}-1$ was unusual in that the heavy internal deposition terminated suddenly, well before reaching the exit rim.

Nozzle N-3. Tefion PFA (Perfluoroalkoxy).

Partial throat blockage allowed some scale buildup (Fig. A-2). Deposits could be flaked off more readily than with Teflon TFE. 


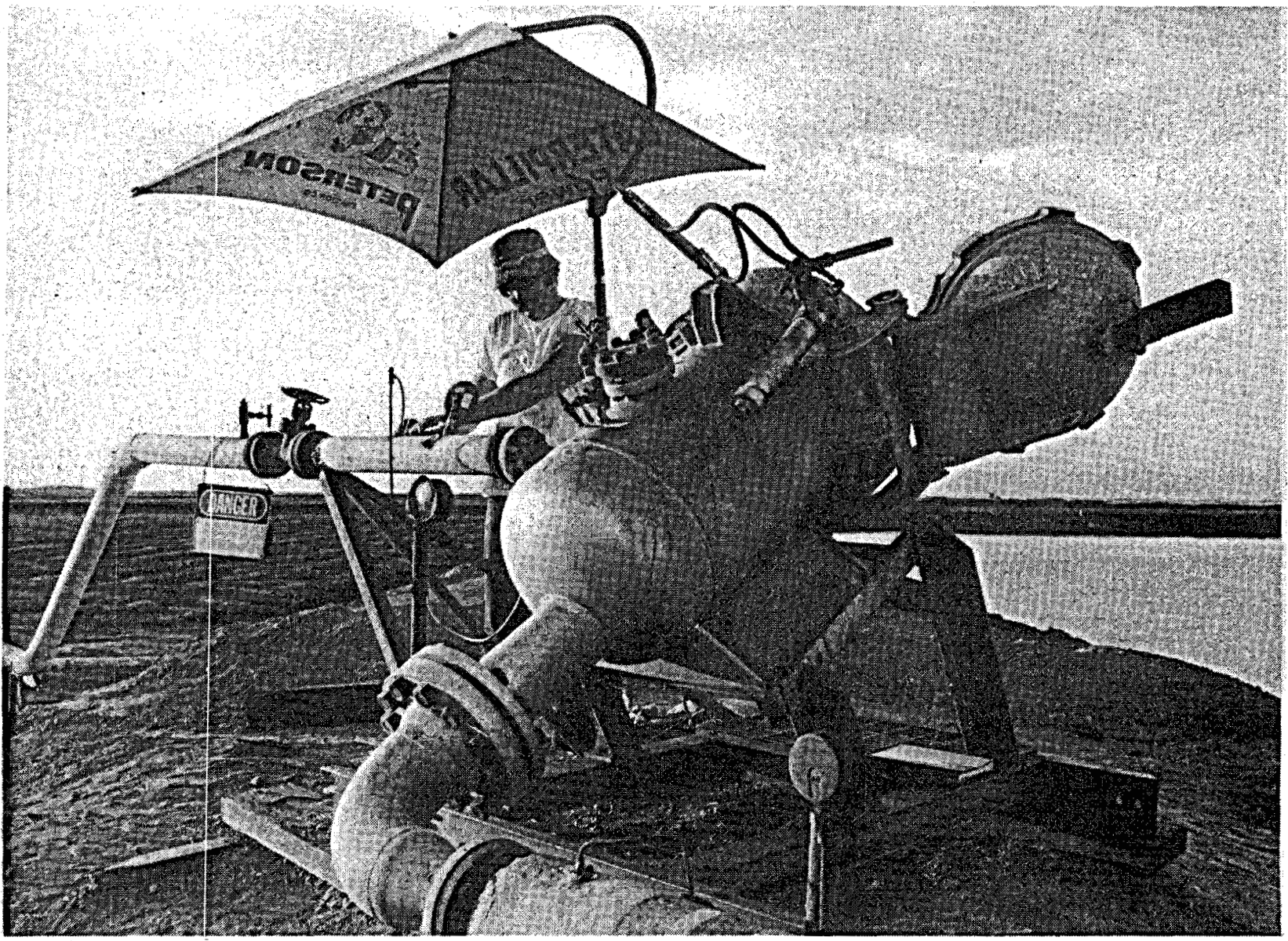

F1g. 4. Rear view of chamber for fleld testing nozzles and wear plates.

Nozzle N-4. Teflon PFA (Perfluoroalkoxy).

No throat blockage occurred, and a very thin scale coating resulted in the cleanest nozzle in the group (Figs, A-3, A-4 and $A-5)$. In the throat end, two sma11 areas of thick filamentary growth could be seen. Magnification showed them to be similar to flat leaves in contrast to the fine hairs found beneath the scale with Tefion TFE (see description of nozzle $\mathrm{N}-15$ ).

Nozzles $\mathrm{N}-5$ and $\mathrm{N}-6$. DuPont KS Resin (Polyamide)

One sample had debris partially blocking flow, but in the other the throat area was badly eroded, leaving essentially a straight tube (F1g. A-6).

Nozzle N-13. Polyphenylquinoxaline.

Plugging had taken place, and very heavy scale buildup was present (Fig. A-7). Some very thin scale on the outside of the barrel could be flaked off very readily.

Nozzle N-15. Teflon TFE (Polytetrafluoroethylene, PTFE).

Some scale buildup was evident and was estimated to be more than with the Tef1on PFA in $\mathrm{N}-4$. When the scale at the exit end was broken away, very fine hairs could 


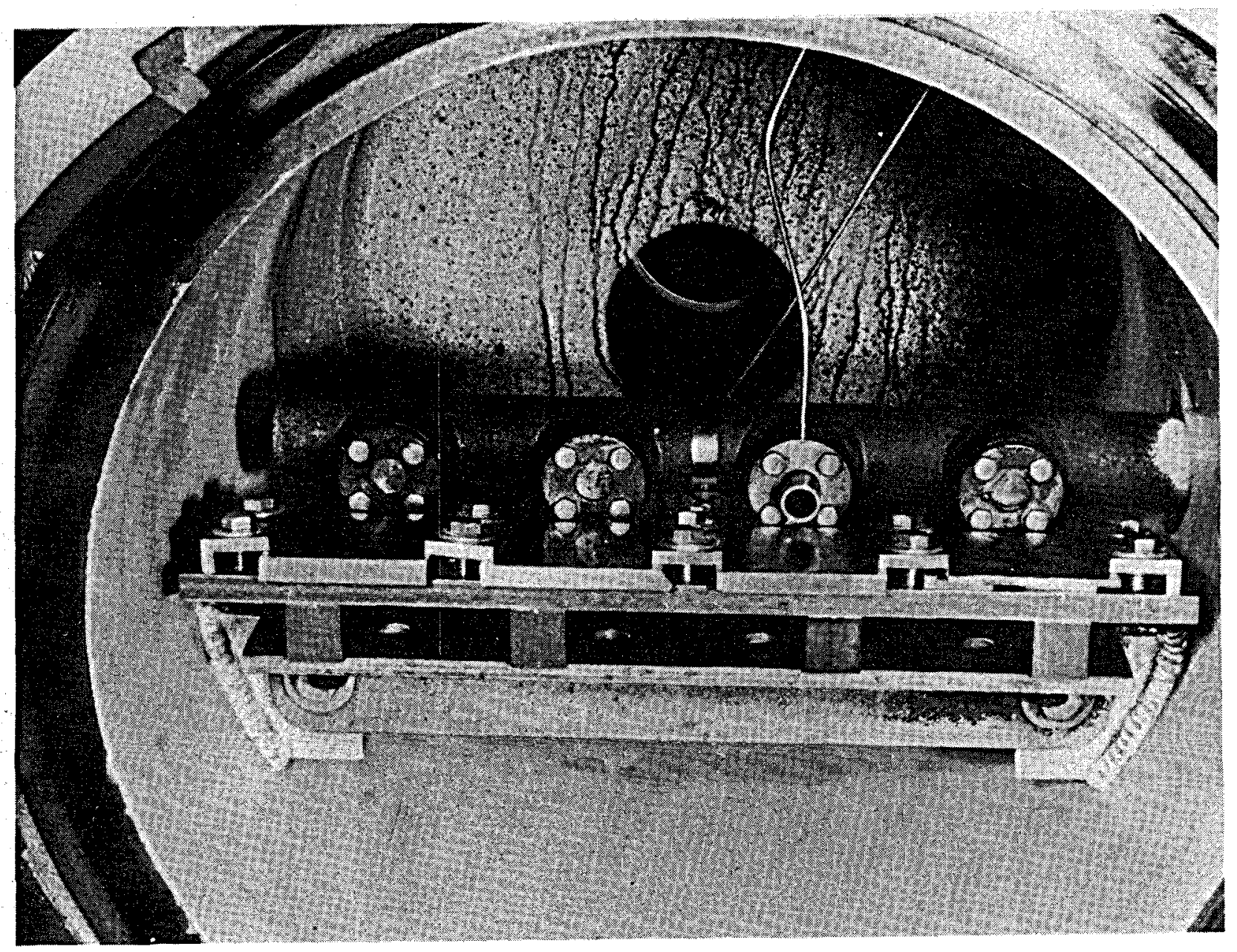

Fig. 5. Front view of test chamber for field testing nozzles and wear plates.

be seen at the Teflon surface (Figs A-8 through A-11). Scanning Electron Microscopy indicated that these hairs were non-conducting and thus were most probably Teflon TFE. PTFE has some unusual characteristics which might account for such behavior. For example, when a second polymer is molded against PTFE, fluorine is found on the new surface, showing that transfer of PTFE has occurred. (See Ref. A1 of Appendix.) Material transfer is also thought to be involved in frictionreduction properties of PTFE. The highly crystalline nature of PTFE may encourage formation of fibrils, a process analagous to the yielding of thin plates in the case of highly structurally organized graphite and mica. Such PTFE fiber formation is in fact, taken advantage of in a new product (Teflon $K$ ) which yields a very fine "hairnet" dust reducing structure when mixed or ground with various powders. The abrasive action of the high-speed expanding stream in the nozzle exit area could induce this fibril formation. Such fibers, if not immediately removed, could initiate scale formation, either by trapping preformed particles capable of further growth, or by acting as nucleating sites for crystal growth as suggested by Fig. A-11. 
TEST RESULTS ON WEAR PLATES

Wear Plate WP-2. Teflon TFE, (Polytetrafluoroethylene):

This wear plate was moderately warped, with a distinct valley eroded into the surface where the stream from the nozzle had Impinged upon it (Figs. A-12 and A-13). The valley had begun to fill with scale. The surfaces struck by the stream were covered by grooves and sharp cuts contain- ing scale particles. Tiny hairs or fibrils were present on these surfaces.

Wear Plate WP-4. Teflon PFA (perfluoroalkoxy).

Very little erosion took place and little scale deposition was observed except at the sides of the impact area (Figs. $A-14$ and $A-15)$. The surface was no longer smooth, but covered with tiny bumps which might have been softened at some point since they lacked sharp edges or fractures.

\section{Equipment}

Equipment for testing material samples included two $300 \mathrm{cc}$ stainless steel pressure bombs ${ }^{2}$, and two $100 \mathrm{cc}$ bombs. Tantalum bomb liners and sample supports were used in place of the quartz liners and supports that had been employed in earlier tests. Type 316 stainless steel thermocouple shields withstood immersion in brine for several hundred hours in contrast to type 347 stainless steel which corroded through in a few hours. The following additional equipment was used in the preparation of test specimens:

\begin{tabular}{|c|c|c|c|c|}
\hline Equipment type & Size (cm) & $\begin{array}{r}\text { Max } \\
\text { Pressure } \\
\end{array}$ & $(\mathrm{MPa})$ & $\begin{array}{c}\text { Max } \\
\text { Temp }\left({ }^{\circ} \mathrm{C}\right)\end{array}$ \\
\hline Buehler specimen press & Cylinder: $\quad 3.12$ diam $x \quad 3.81$ & 68.9 & & 427 \\
\hline Cylindrical mold & Cylinder: $7.62 \mathrm{~d} 1 \mathrm{am} \times 10.2$ & 310 & & 427 \\
\hline Flat-disc mold & Cylinder: 15.2 diam $\times 3.12$ & $>68.9$ & & 427 \\
\hline Frame mold & $10.2 \times 10.2 \times 0.64$ & 6.89 & & 427 \\
\hline Bar mold & $2.54 \times 0.64 \times 15.2$ & 6.89 & & 427 \\
\hline Cylindrical mold & 3.12 diam $\times 10.2$ & 517 & & 427 \\
\hline
\end{tabular}




\section{Part Fabrication}

Using procedures recommended by the manufacturers, we fabricated parts from Ryton polyphenylene sulfide, Eckonol 900 polyester, NR150B polyimide, Kerimid 601/ Thornel 400 composite, and phenolic/ fiberglass. Other samples were received from manufacturers as machinable stock shapes. Some 39 companies have been contacted with regard to supplying materials and parts.

\section{Future Work}

We will continue looking for new materials, as well as fabricating and testing them in the form of polymers, composites and coatings. Screening will include: (a) static hot brine tests, (b) testing at the LLL geothermal test facility (now being completed) to study erosion and temperature-resistance, (c) mechanical testing of exposed specimens, and (d) several types of field tests. A series of field tests was concluded in May, 1975 and results will be reported shortly. Field tests are extremely important for measuring scaling resistance, a critical factor in successful operation of a nozzle/turbine system. The rapid rate of scale buildup is illustrated in Figure 6, where an $11.4 \mathrm{~cm}$ o.d. epoxy/ fiberglass pipe with walls $0.64 \mathrm{~cm}$ thick collected $1 \mathrm{~cm}$ of scale during 5 to 6 days as a post-expansion drain line. Material hardness and surface finish as well as surface chemical type will be examined for scaling resistance.

\section{Acknowledgments}

The field testing of nozzle- and wearplate specimens by J.M. Johnson and D. B. Clifton is gratefully acknowledged, as is the Scanning Electron Microscopy work of J. Steele. Credit is also due the numerous companies who provided samples of materials for testing. 


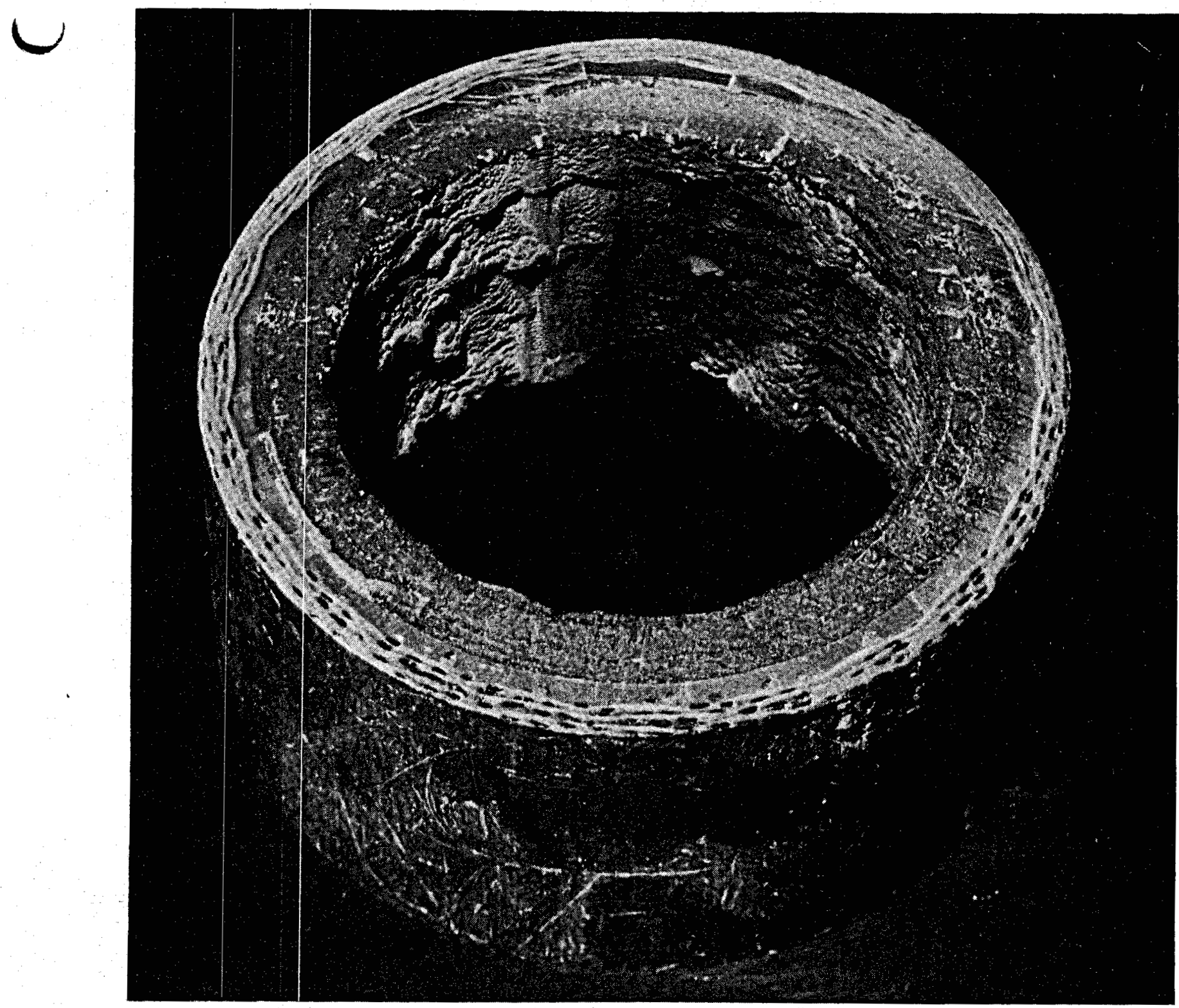

Fig. 6. Epoxy/fiberglass pipe containing scale. 


\section{References}

1. A. L. Austin, G. H. Higgins and J. H. Howard, The Total Flow Concept for Recovery of Energy from Geothermal Hot Brine Deposits, Lawrence Livermore Laboratory, Rept. UCRL-51366 (1973).

2. L. E. Lorensen, Materials Screening Program for the LLL Geothermal Project, Lawrence Livermore Laboratory, Rept. UCID-16513 (1974).

3. G. R. Berbeco, E. O. Hook, E. L. Lowdermilk, "The Structure and Properties of Polyimides", Proc. Conf. Am. Chem. Soc., 160th, Chicago, 1970 (American Chemical Society, Washington, 1970) pp 169-174.

4. N. Adrova, M. E. Bessonov, L. A. Laius, A. P. Rudakov, Polyimides, A New Class of Heat-Resistant Polymers (IPST Press, Jeruselam, 1969).

5. L. E. Lorensen, SAMPE Q 6 , 2 (Jan. 1975), pp 1-13. 


\section{Appendix}

DETAILED TEST RESULTS ON NOZZLES

Nozzle N-1. Carbon Fiber or Felt.

Impregnated with Carbon Via the Carbon

Vapor Deposition (CVD) Process.

Several large pieces of scale were embedded in the pre-throat entry section. Black deposits were covered with a thin layer of easily removed orange deposit: The nozzle was stuck in its steel holder. Considerable black scale was stuck to the outside of the barrel and was difficult to remove. The exit end was clean 2 to $4 \mathrm{~mm}$ down, with no sign of erosion (FIg. $A-1)$. Heavy deposits began at that point, reducing the throat to $3-4 \mathrm{~mm}$.
These forward surfaces had fine white salt deposits on them.

Nozzle N-3. Teflon PFA (Perfluoroalkoxy). This nozzle had not expanded and was easily removed from its holder. The flat face of the entry end was clean. The prethroat areas had thin black, glassy coatIngs covered with an orange film and scale broke away falrly cleanly. The throat was about half blocked with pieces of scale which had come down the pipe. The outside of the barrel was quite clean. The exit end was 11ned with approximately $1 \mathrm{~mm}$ of black scale, beneath which was an orange deposit at the interface (FIg. A-2).

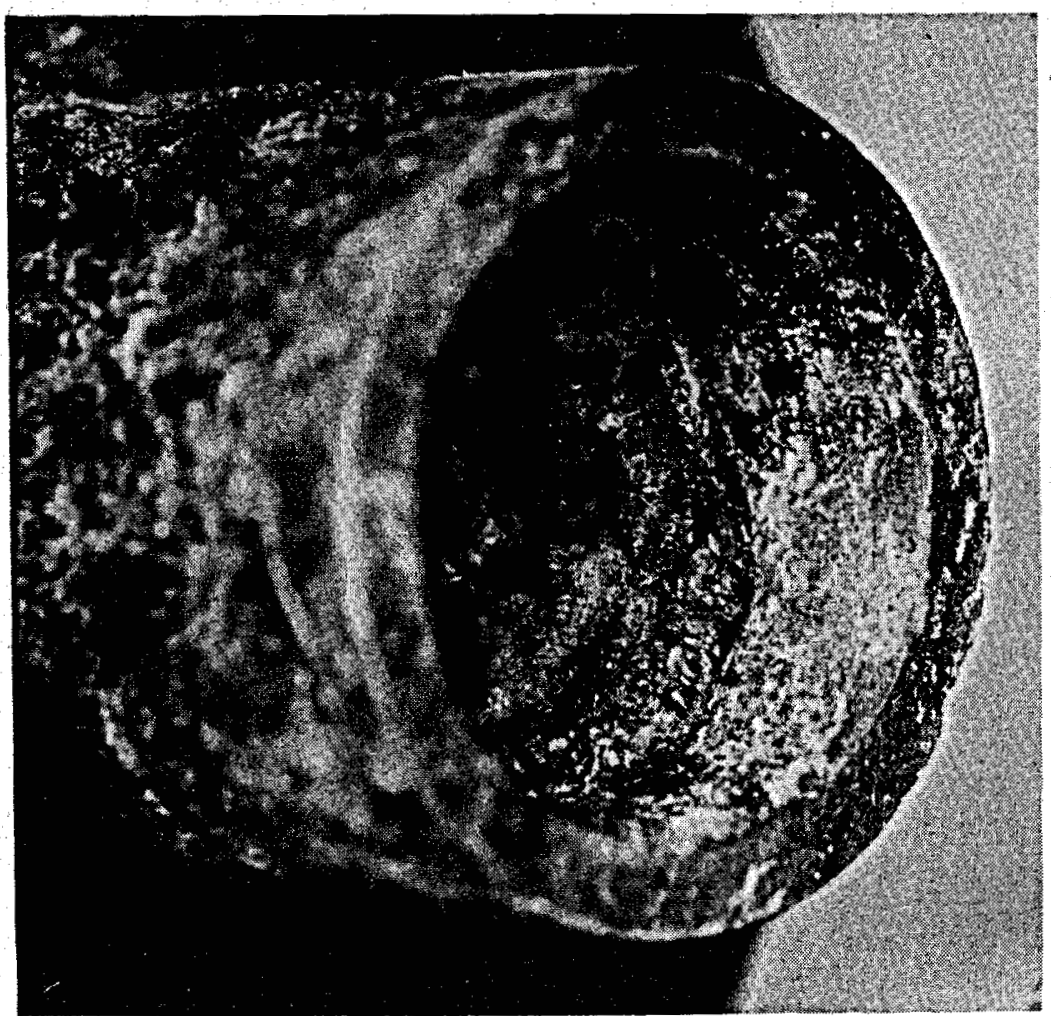

Fig. A-1. Carbon/carbon fiber nozzle $\mathrm{N}-1$, exit end. 


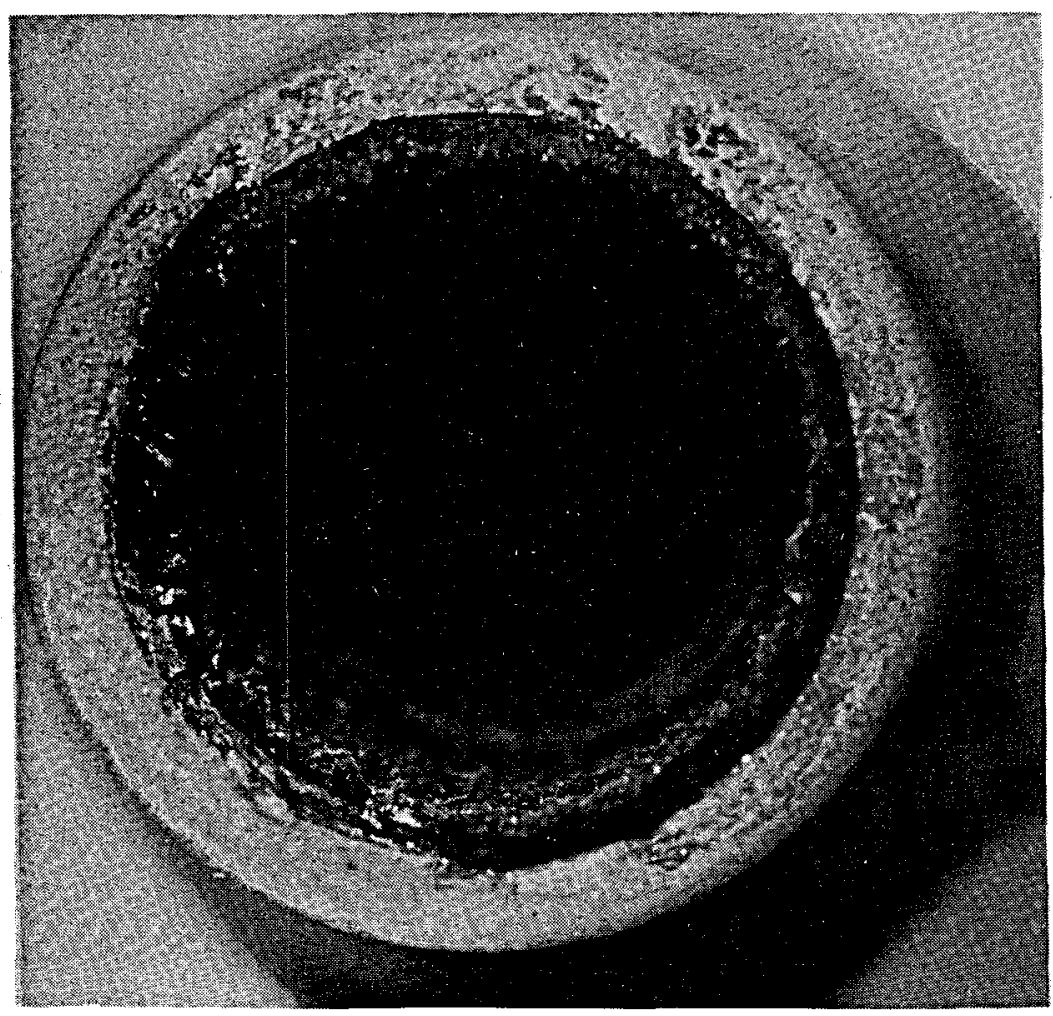

Fig. A-2. Teflon PFA nozzle $\mathrm{N}-3$, exit end.

These deposits could be flaked off relatively easily, perhaps more readily than with Teflon TFE. With magnification, few if any fine surface hairs could be seen, In contrast to the hair "growth" on Tefion TFE (see the report on nozzle N-4, below).

Nozzle N-4. Teflon PFA (Perfluoroalkoxy). Although a duplicate of $\mathrm{N}-3, \mathrm{~N}-4$ did not become clogged with debris. Some very thin deposits were present in the prethroat area. In two small areas, deposits were absent, and under magnification bushlike flexible matts of polymer could be seen. At $500 \mathrm{X}$, leaves or flaps of polymer (nonconducting in SEM) appeared, with small particles of debris present. The nozzle outer surfaces were clean, and the exIt-end inner surfaces were covered with a very thin black coating. No erosion was noted. See Figs. A-3, A-4 and A-5.

Nozzle N-5. DuPont KS Resin (Polyamide): This nozzle was wedged in the steel retaining plate. Outer surfaces were quite clean (Fig. A-6. The throat restriction had been entirely eroded away, leaving essentially a straight tube with little deposit present.

Nozzle N-6. DuPont KS Resin (Polyamide). The pre-throat or entry area looked somewhat eroded, but with compensating scale present. It was almost half blocked with debris and well scaled. The throat had eroded little, and the exit-end surfaces were covered with only a very light scale, colored black with some white surface coating over part of the area. No erosion was visible at the exit end. 


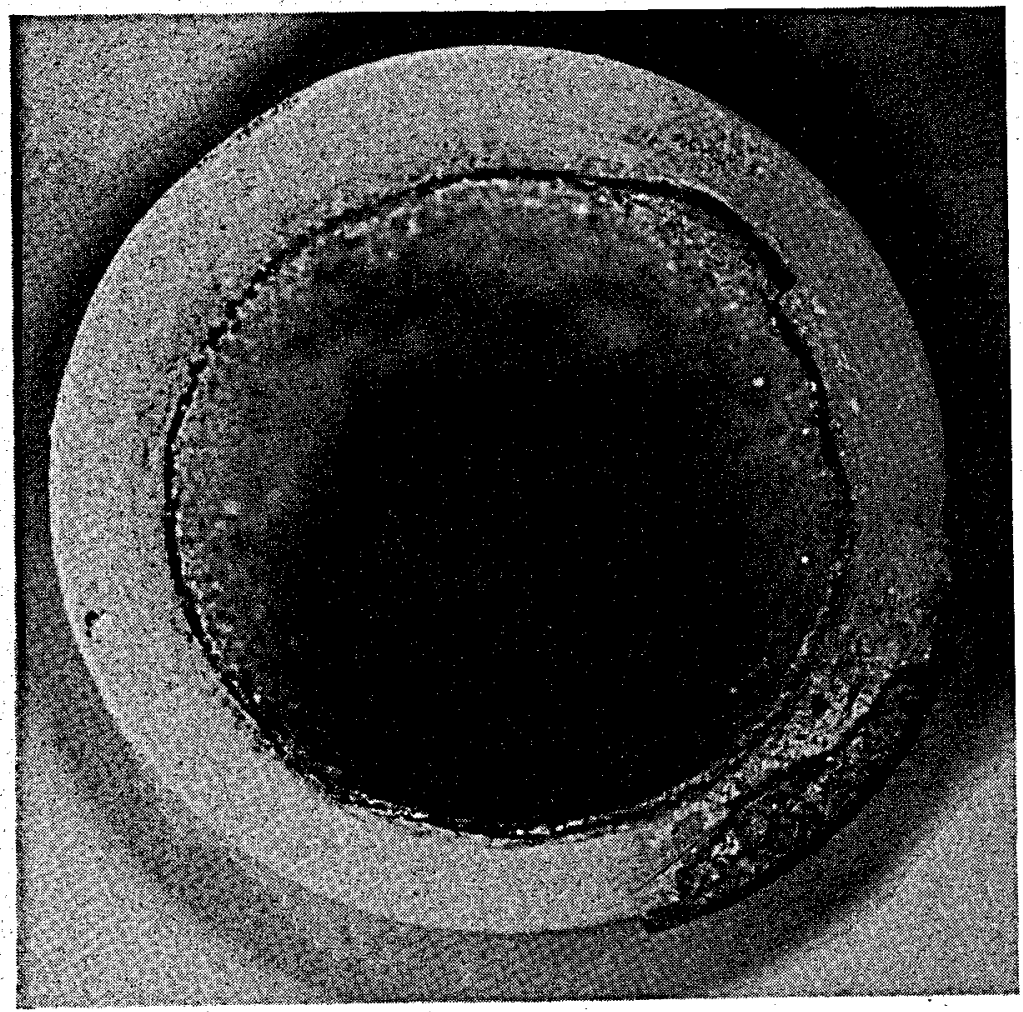

F1g. A-3. Teflox PFA nozzle N-4, exit end.

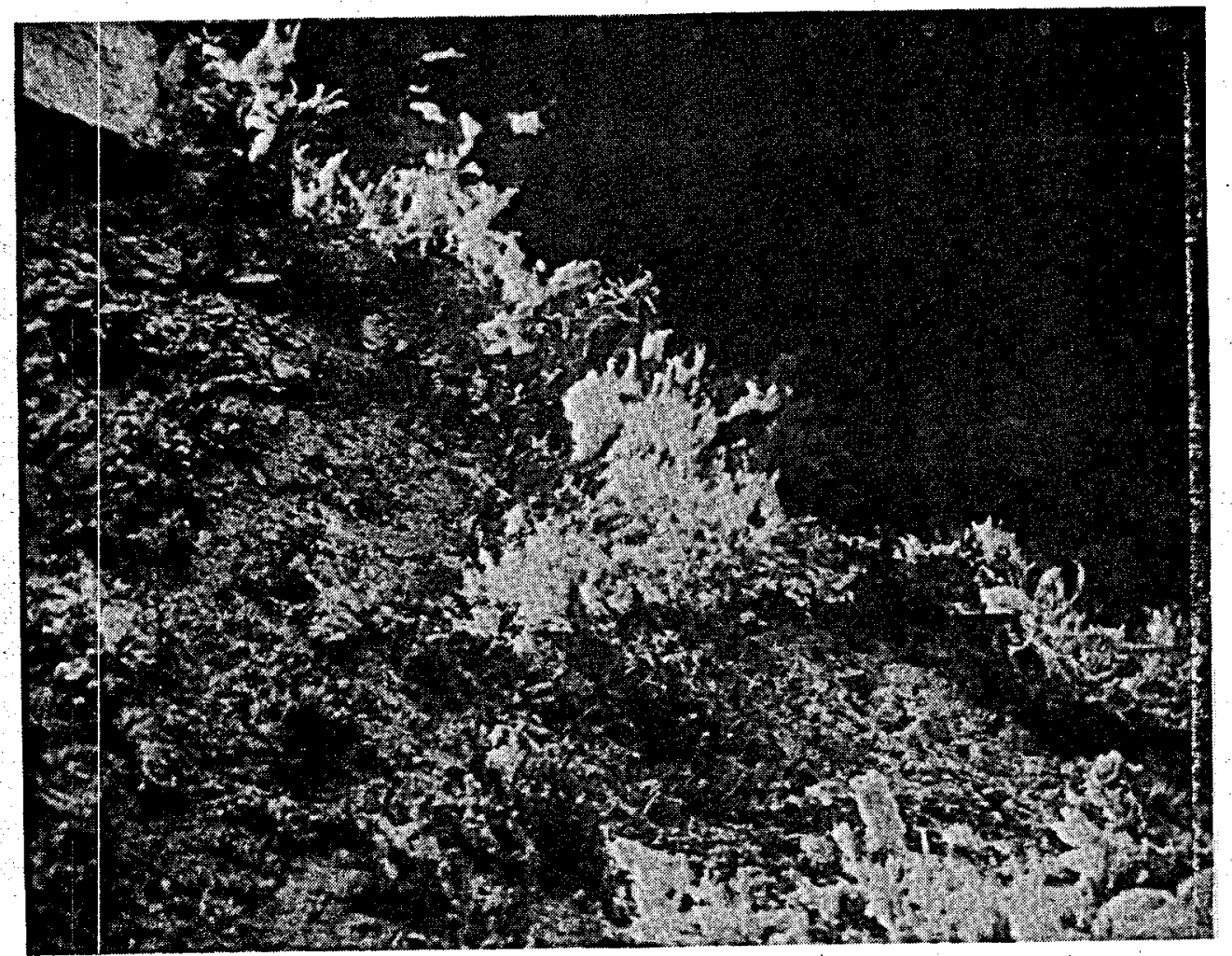

Fig. A-4. Teflon PFA nozzle N-4, bush growth in entry end $(20 \mathrm{X})$. 


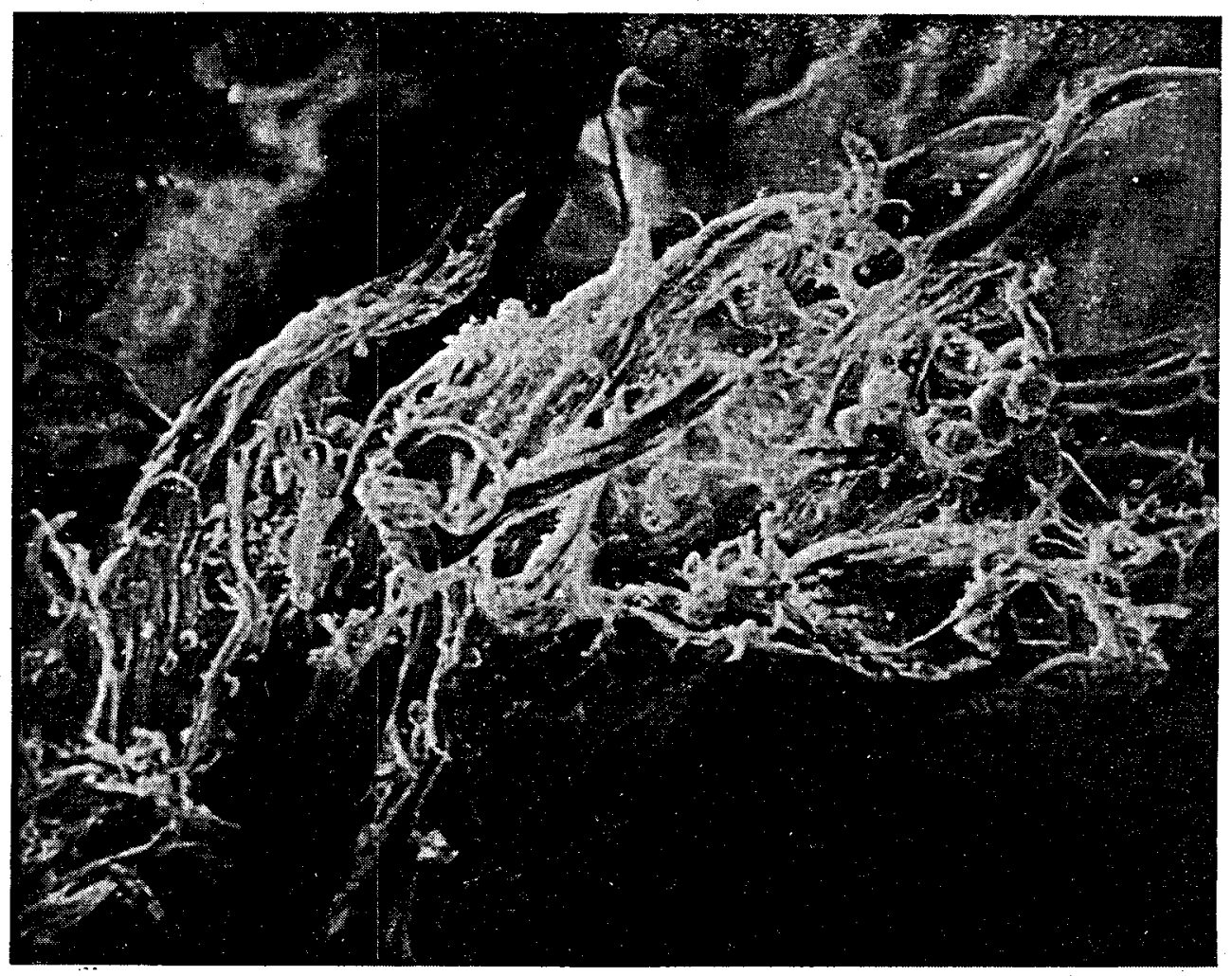

Fig. A-5. Teflon PFA nozzle N-4, bush in entry end (500 X).

Nozzle N-13. Polyphenylquinoxaline.

This nozzle (Fig. A-7) was stuck in its holder. The entry end was apparently completely blocked with pieces of debris "welded" together with scale deposit. The outside of the barrel was covered with very thin (less than a few tenths of a millimeter), spotty yellow deposit which could be flaked off very easily. The exit end had an "extruded" scale buildup, 2 to $3 \mathrm{~mm}$ beyond the rim, with a 6- to 7mm hole remaining.

Nozzle N-15. Teflon TFE (Polytetrafluoroethylene, PTFE).

The nozzle could be rotated, but not removed from the holder, indicating that some expansion due to plastic flow had taken place. (Figs. A-8 through A-11).
The inside of the entry end was coated with a two-layer black deposit a few tenths of a millimeter thick. The layers were brittle, separable and did not adhere strongly. The black color changed to white in the restricted throat area which was closed down to a diam of 6 to $7 \mathrm{~mm}$. The outside of the barrel was about half covered with patches of orange and brown deposit which readily flaked off. At the exit end, there was about $1 \mathrm{~mm}$ of "extrusion" deposit extending beyond the rim. This was black "warty" material covered with orange powder. When it was broken away from the rim, a large number of very fine hairs could be seen (even at $40 \mathrm{X}$ magnification) in the area where the deposit had been. In Fig. A-11 (magnification $1500 \mathrm{X}$ ) crystal growth appears to be nucleated on the hairs. 


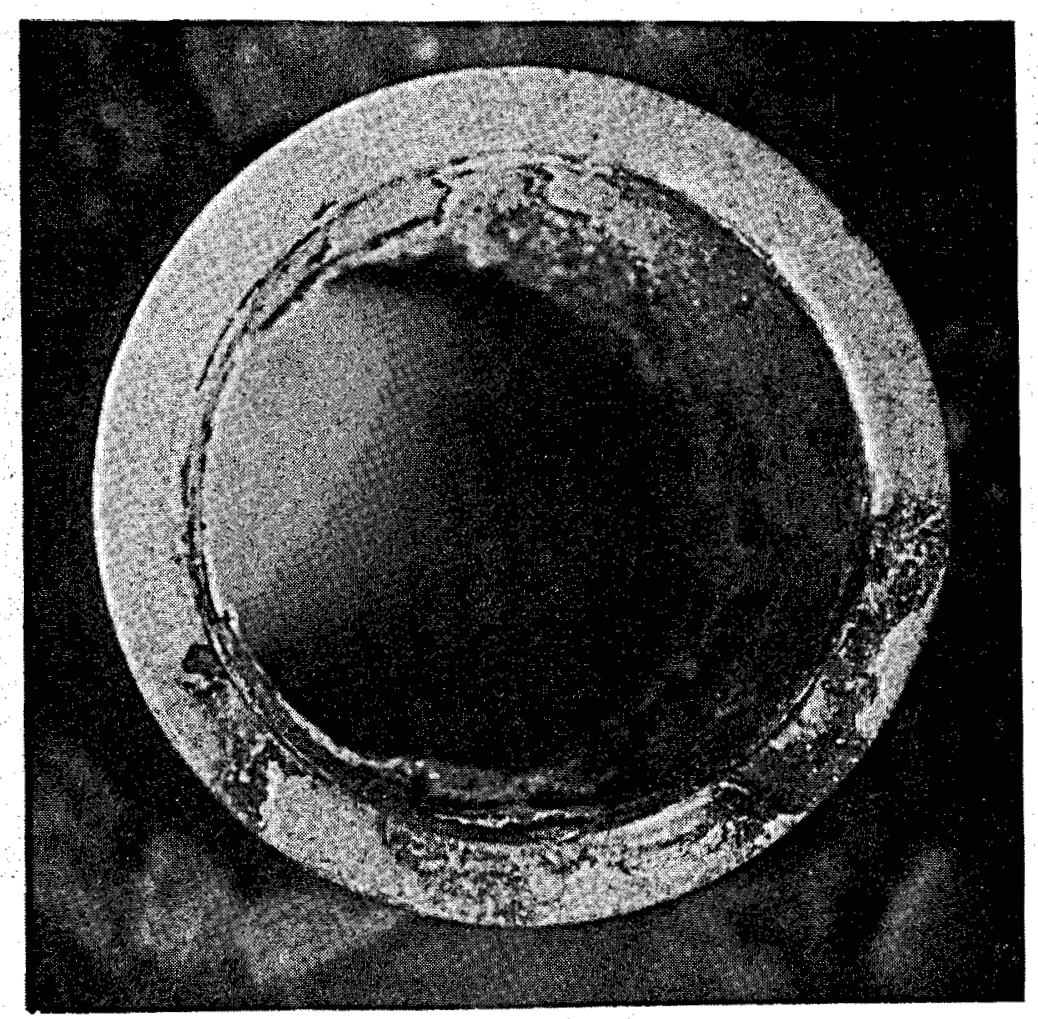

Fig. A-6. Polyamide KS resin nozzle $\mathrm{N}-5$, exit end.

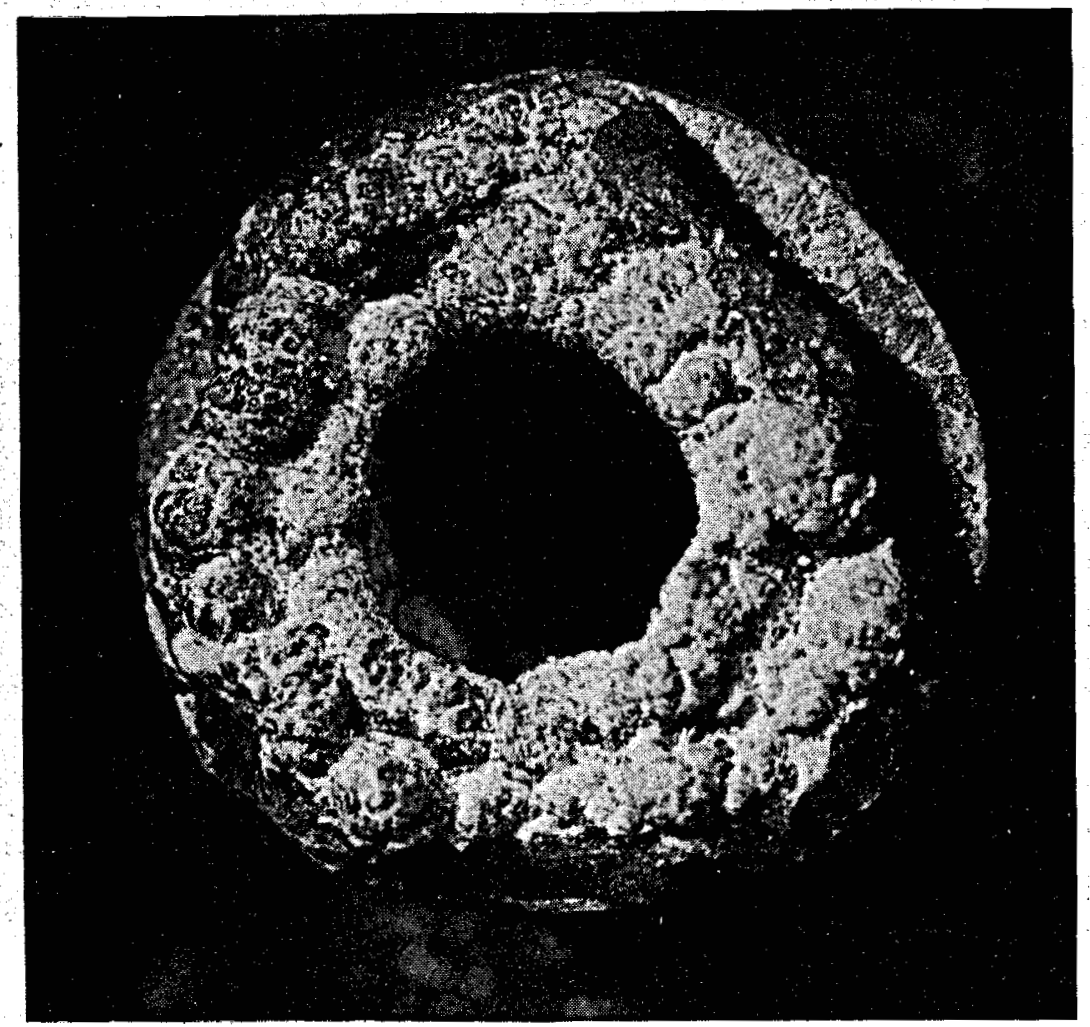

Fig. A-7. Ployphenylquinoxaline nozzle $\mathrm{N}-13$, exit end. 


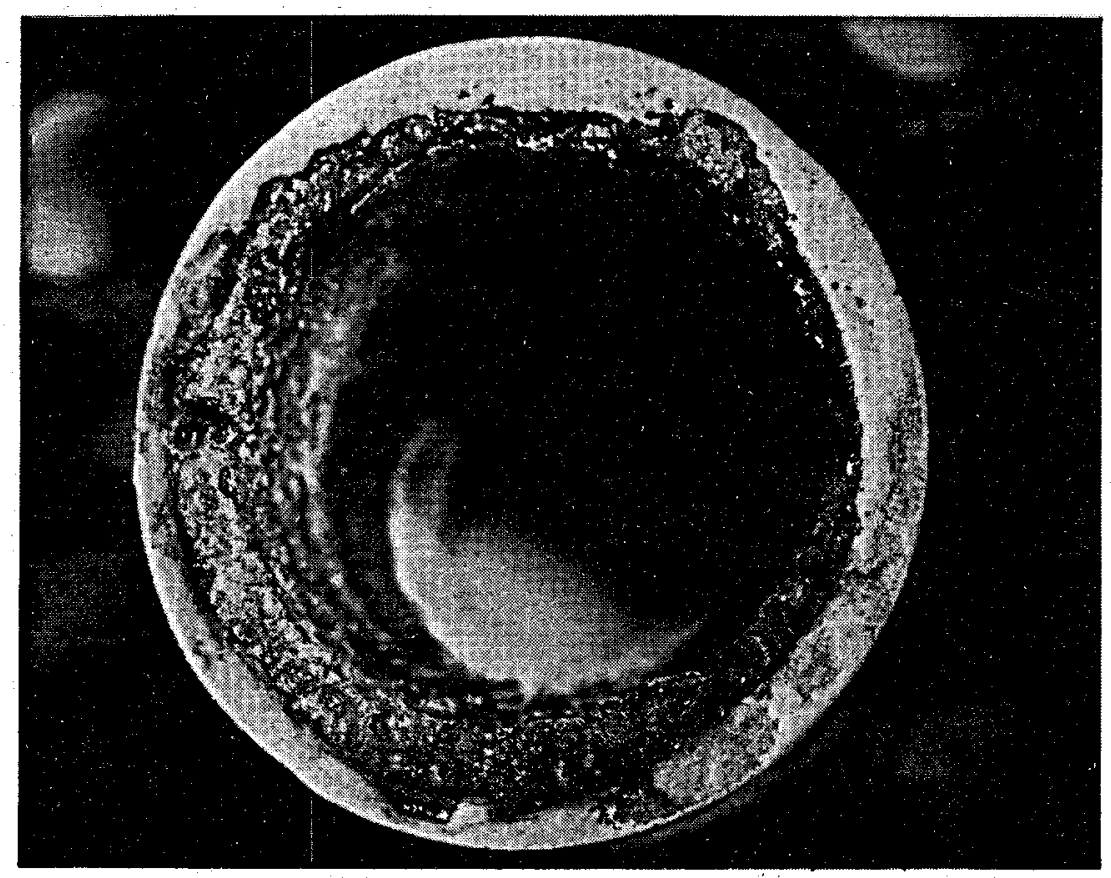

Fig. A-8. Teflon TFE nozzle $\mathrm{N}-15$, exit end.

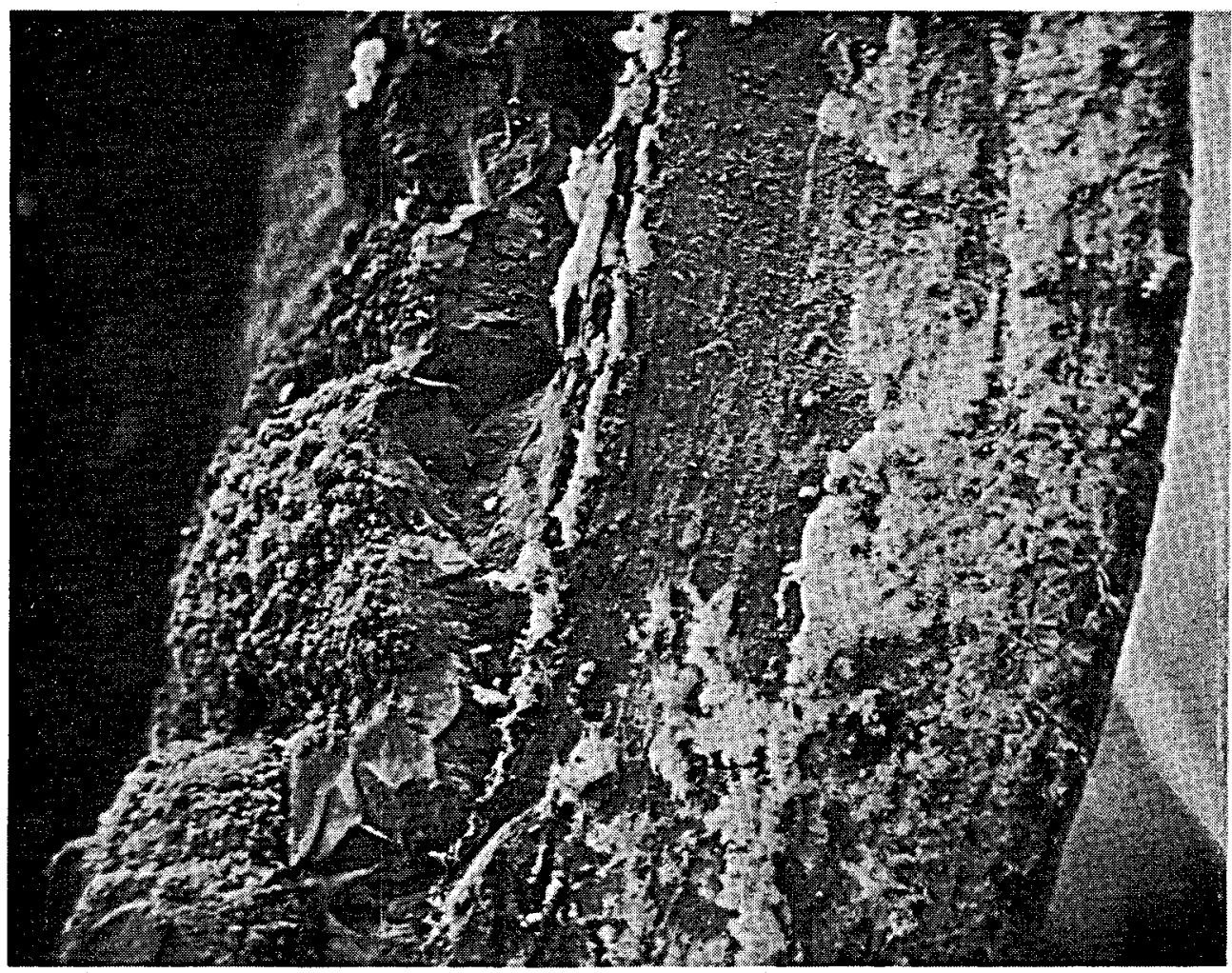

Fig. A-9. Teflon TFE nozzle $\mathrm{N}-15$, showing scale-resin interface at exit end (25 X). 


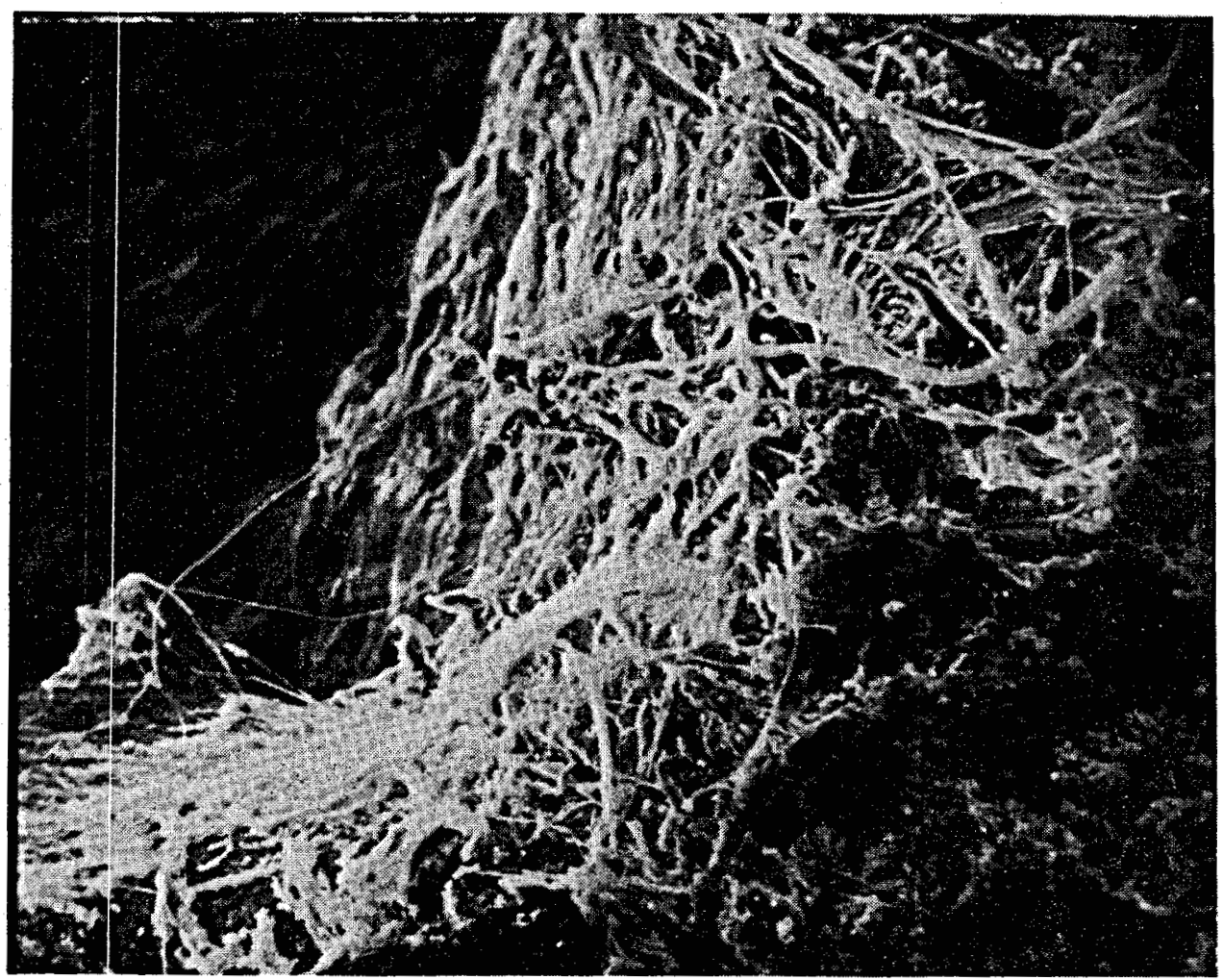

Fig. A-10. Teflon TFE nozzle N-15, showing fibers at scale-resin interface (650 X).

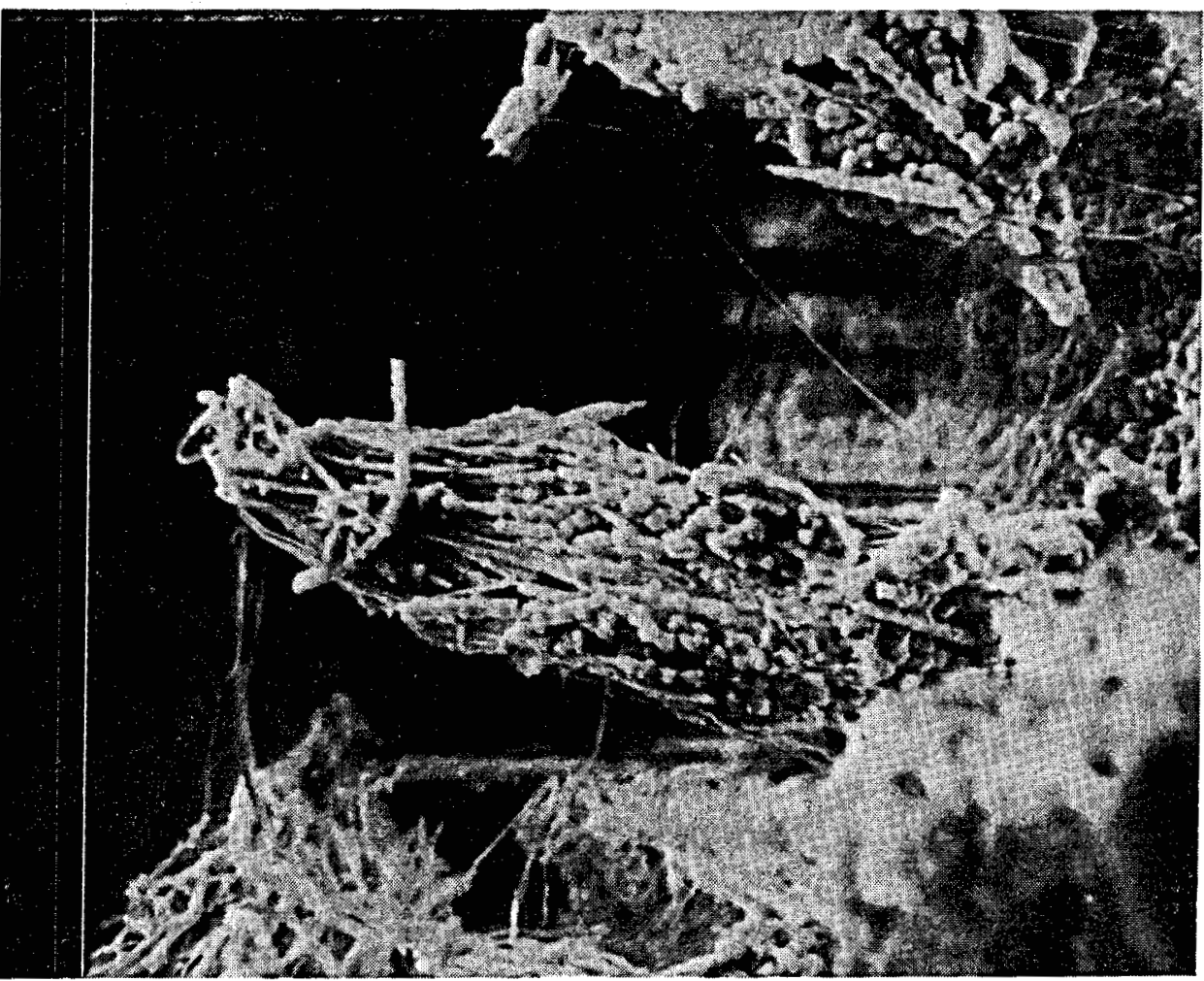

Fig. A-11. Teflon TFE nozzle N-15, showing fibers with probable scale growth (1500 X). 
Wear Plate WP-2. Teflon TFE (Polytetrafluoroethylene).

This plate (Figs $\mathrm{A}-12$ and $\mathrm{A}-13$ ) was tested for 108 hours. At completion of Wear P1ate WP-4. Tef1on PFA (Perf1uoroalkoxy).

After $132 \mathrm{hr}$ exposure a definite darker the test, the plate was moderately warped. Impact area could be seen, but little if The stream from the nozzle had worn a depression about $1.6 \mathrm{~cm}$ wide, $4.4 \mathrm{~cm}$ long and at least $0.32 \mathrm{~cm}$ deep in the plate. any erosion had occurred (Figs. A-14 and A-15). The surface was roughened by the presence of small bumps, smoothed somewhat The depression had partially filled with scale at the far end. On removing a few small chips of this scale, it was found that the polymer surface had been markedly roughened by grooves, cuts, and sharp, by possibly having once been molten or softened. Some small black particles were buried, either by impact penetration or localized flow. Light brown debris particulate was present on the surface. A thin, angular flaps or projections. Almost a11 cuts had black deposit in the bottom. The glassy brittle film of transparent material on the surface made it look quite shiny. surface was also covered with a very fine, delicate web or network of flexible hairs or fibers. This web held many smaller This could have been a salt film left behind by evaporation of fluid remaining after the test was completed.

\section{References}

Al. R. G. Azrak, Chemtech (Nov. 1974), pp 683-689.

A2. R. F. Welch, Jr., J. Teflon 16, 1 (1975), p 6 .

$\mathrm{IMM} / \mathrm{grw}$ 


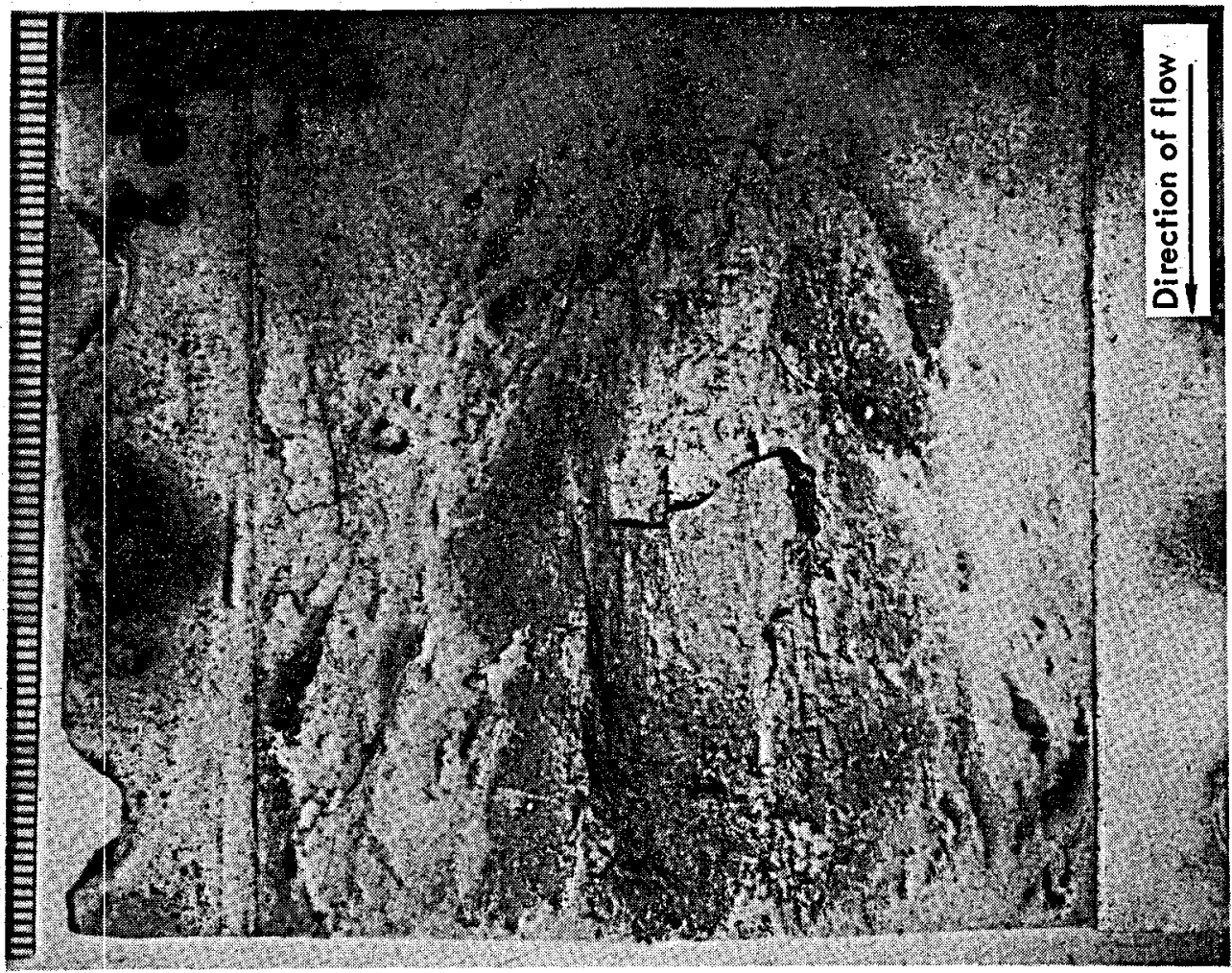

Fig. A-12. Teflon TFE wear plate WP-2, showing erosion. (1 div $=1 \mathrm{~mm})$.

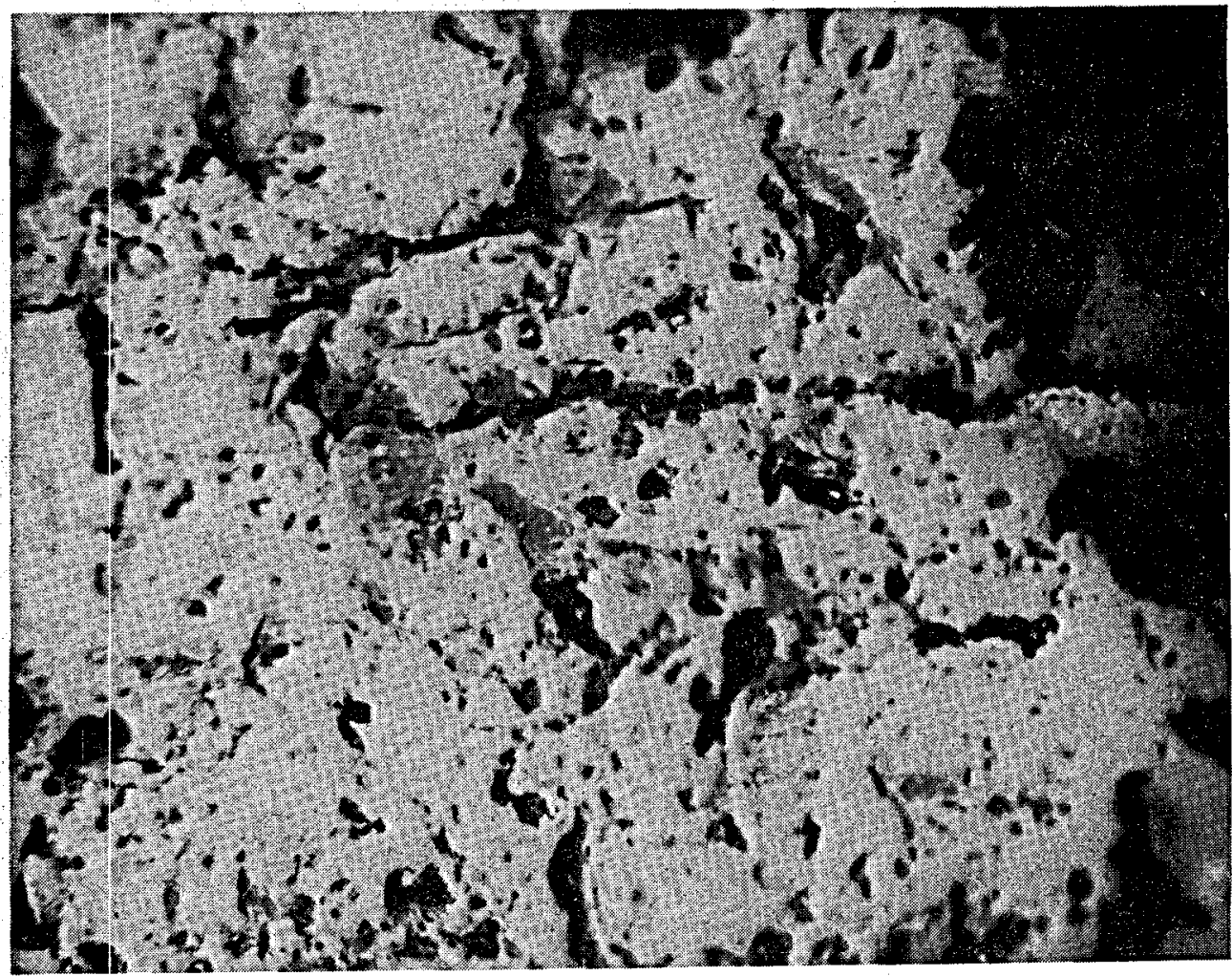

Fig. A-13. Teflon TFE wear plate WP-2, showing surface features (30 X). 


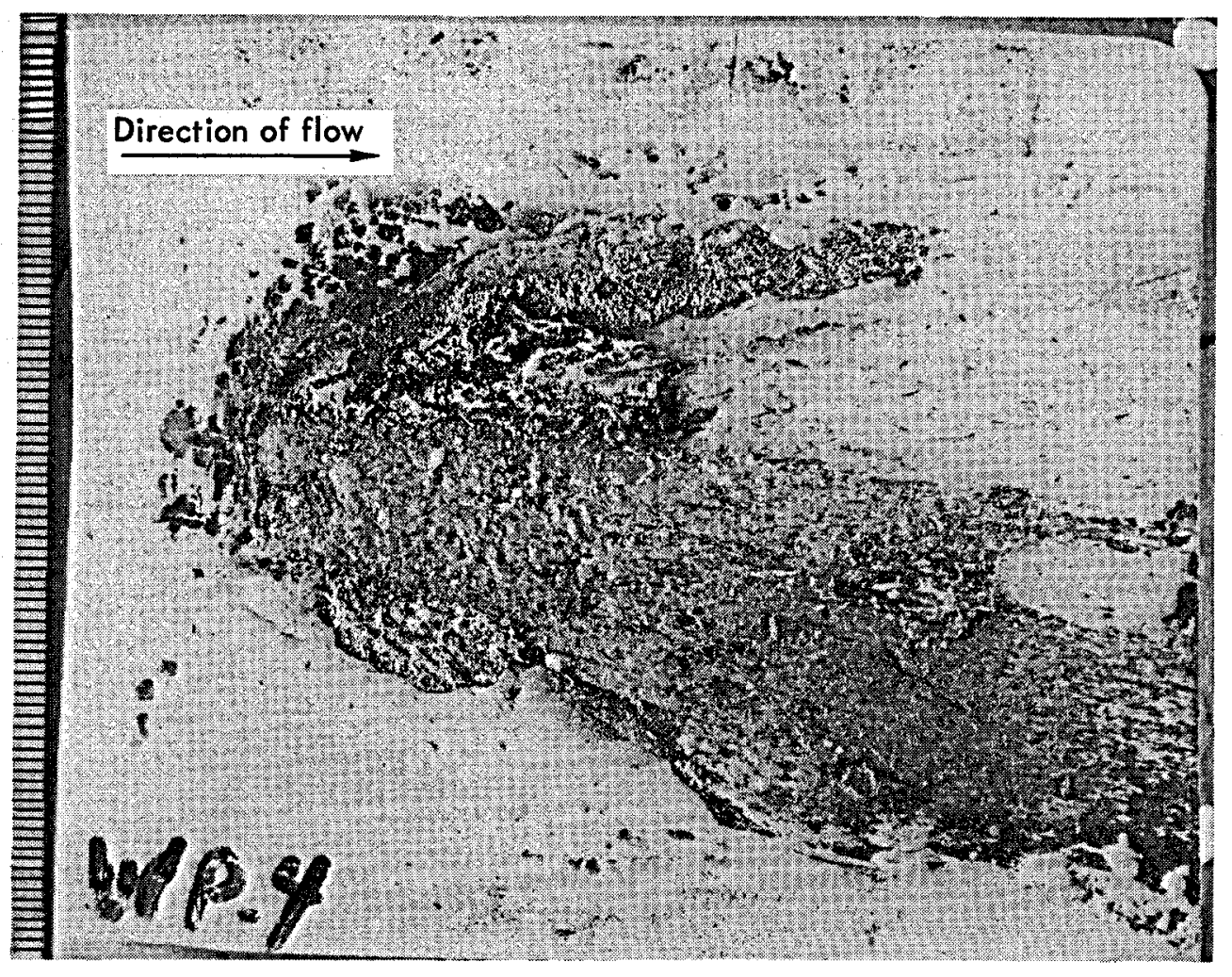

Fig. A-14. Teflon PFA wear plate WP-4 (1 div = $1 \mathrm{inm})$.

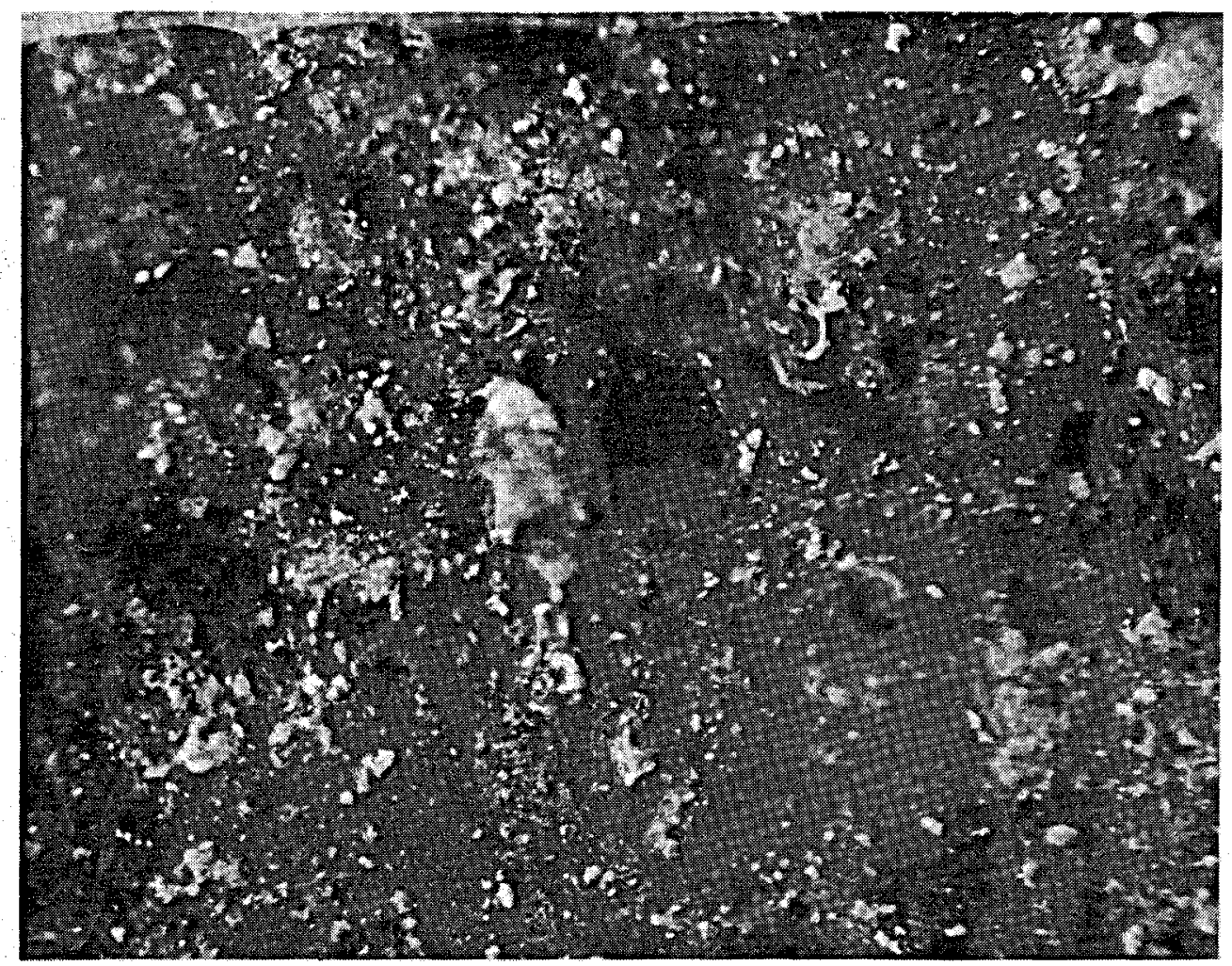

Fig. A-15. Teflon PFA wear plate WP-4, showing surface features (30 X). 